\title{
A Theory Of Good Governance Or Good Government
}

\author{
Jan-Erik Lane \\ Professor emeritus at UNIGE, Geneva, Switzerland
}

\begin{abstract}
The United Nations' endorsed notion of good government or governance can be analysed in a clear fashion with the concepts of rule of law - rule of law I (legality) and rule of law II (democracy). Principal-agent modelling shows how politicians and the bureaucracy can be restrained by rule of law institutions.
\end{abstract}

Keywords: rule of law, good governance, radical Islam. Asian authoritarianism

\section{INTRODUCTION}

Good governance or good government entails limited government, i.e. a political regime that respects the rule of law.. Moreover, limited government in relation to civil society implies a state that operates under certain key rules (Bradley and Ewing, 2010):

i) Legality: government is exercised by means of laws, enforced ultimately by an independent judiciary;

ii) Lex superior: there is a higher law - the constitution - that guarantees certain rights for the citizens, like e.g. equality under the law, due process of law and habeas corpus;

iii) Trias politica: executive, legislative and judicial powers are to be separated;

iv) Accountability: Governments can be held responsible for their actions and non-actions through various established procedures of criticism and complaint, enquiry and removal from office as well as redress;

v) Representation: The people have a SAY somehow in government through representative institutions.

These principles above emerged hundreds of years ago, long before democracy was introduced in many countries at the end of the First World War in Europe and America (Lloyd, 1991; McIlwain, 1958; Neumann, 1986). Today all existing democracies endorse these constitutional principles in the form of constitutional democracies.

Rule of law I, whether combined with any form of democracy - referendum type, parliamentary type, presidential dispensation - or not, as in semi-democratic countries that are one party states, comprises: Predictability: Public law when properly implemented makes it possible for people to increase the rationality of behaviour. They know what rules apply, how they read as well as how they are applied consistently. This is very important for the making of strategies over a set of alternatives of action. Transparency: Societies operate on the basis of norms prohibiting, obligating or permitting certain actions in specific situations. Rule of law entails that these norms are common knowledge as well as that they are not sidestepped by other implicit or tacit norms, known only to certain actors. Due Process of Law: When conflicts occur either between individuals or between persons and the state, then certain procedures are to be followed concerning the prosecution, litigation and sentencing/incarceration. Thus, the police forces and the army are strictly regulated under the supervision of courts with rules about investigations, seizure, detainment and prison sentencing. No one person or agency can 
take the law into their own hands. Fairness: Rule of law establishes a number of mechanisms that promote not only the legal order, or the law, but also justice, or the right. For ordinary citizens, the principle of complaint and redress is vital, providing them with an avenue to test each and every decision by government, in both high and low politics. Here one may emphasize the existence of the Ombudsman, as the access to fairness for simple people. People have certain minimum rights against the state, meaning that government respects obligations concerning the protection of life and personal integrity. Thus, when there is due process of law - procedural or substantive - one finds e.g. the habeas corpus rights (Raz, 2009).

Some 50 per cent of the world cherish rule of law in the strong or thick meaning, i.e. rule of law I combined with popular democracy - rule of law II. Its spread is partially linked with the level of human development, which is a function of economic output to a considerable extent. However, countries that implement rule of law II also establish rule of law I, i.e. legality and rights. It is the opposite that does not hold, meaning that several countries honour rule of law I but not rule of law II. In countries where neither rule of law I nor rule of law II exists, political agents face almost no restrictions upon what they may wish to do.

\section{THE TWO CONCEPTS OF “RULE OFLAW"}

In continental political theory, rule of law tends to be equated with the German conception of a Rechtsstaat in its classical interpretation by Kant Reiss, 2005). It signifies government under the laws, i.e. legality, lex superior and judicial autonomy (rule of law I). In Anglo-Saxon political thought, however, rule of law takes on a wider meaning, encompassing in addition also nonjudicial institutions such as political representation, separation of powers and accountability (rule of law II). In general, the occurrence of rule of law II is a sufficient condition for the existence of rule of law I. But rule of law I - legality and judicial independence - is only a necessary condition for rule of law II - constitutionalism as voice and accountability.

\section{RI: Legality and Judicial Independence}

According to the narrow conception of rule of law, it is merely the principle of legality that matters. Government is in accordance with rule of law when it is conducted by means of law, enforced by independent courts. The law does not need to contain all the institutional paraphernalia of the democratic regime like separation of powers and a bill of rights. The legal order may simply express the authority of the state to engage in legislation, as expounded by legal positivists like e.g. Kelsen (2009) in his pure theory of law. The basic norm implies legislation that in turn entails regulations that implies instructions and commands. However, whatever the nature of the legal order may be, the principle of legality restricts governments and forces it to accept the verdicts of autonomous judges. 2 Countries that lack the narrow conception of rule of law tend to have judges who adjudicate on the basis of short-tern political considerations, twisting the letter of the law to please the rulers. Thus, law does not restrain the political agents of the country, employing the principal-agent perspective upon politics (Besley, 2006).

One observes a connection between socio-economic development and judicial autonomy. Poor and medium affluent countries are not characterized by judicial independence. Yet, besides socio-economic development many other factors impinge upon the institutionalisation of judicial independence like inherited legal system, religion and the party system. When judges are not independent they change their verdicts in accordance with the political climate of the country. Whatever protection the constitution or the law offers in writing for citizens or foreigners visiting a country becomes negotiable when a case is handled by the police. Even if a country does not possess a real constitution with protection of a set of inalienable rights, it still makes a huge difference whether the courts constitute an independent arm of government. 
Thus, also in countries with semi-democracy or with dictatorship, matters become much worse when judges cannot enforce whatever restrictions are laid down in law upon the political elite. The independence of courts is a heavily institutionalised aspect of a mechanism that takes years to put in place. Judges are paid by the state by means of taxation, but the formula of "He who pays the piper calls the tune" does not hold. In order to secure judicial independence from politics and the rulers an elaborate system of appeal has to be erected, meaning that the behaviour of lower court judges will be checked by higher court judges. The standard institutional solution is the three partite division of the legal system with a supreme court at the apex. However, countries may have one than one hierarchy of courts making the judicial system complex. An independent judiciary secures a fair trial under the laws. From the point of view of politics this is important in order to avoid that accusations for any kind of wrong doing is used for political purposes. When there is an autonomous legal machinery in a country, then also politicians or rulers may be held accountable for their actions or non-actions - under the law. This is of vital importance for restricting corrupt practices of various kinds.

\section{RII: Constitutional Democracy}

Legality and judicial independence are not enough to secure rule of law in the broad sense of the term. Broad rule of law involves much more than government under the laws, as it calls for inter alia: separation of powers, elections, representation and decentralisation of some sort. In the WB governance project the broad conception of rule of law is measured by means of the indicator "voice and accountability". Since rule of law II regimes are invariably rule of law I regimes, but not the other way around, countries that score high on voice (of the principal) and accountability (of the agents) can be designated as constitutional states.

There is a positive relationship between socio-economic development and the constitutional state, albeit not as strong as in the classical studies on democracy and affluence (Diamond, 1999). There is a set of countries that deviate from this pattern. On the one hand, a number of countries have reached a high level of socio-economic development without 5 institutionalising the mechanisms of the constitutional state: the Gulf monarchies and the Asian tigers. On the other hand, a set of countries with the constitutional state are to be found at a low level of socio-economic development, mainly India, Botswana and Mauritius. In some Latin American countries there is a medium level of socio-economic development and a medium degree of rule of law institutionalisation. This association between affluence on the one hand and democracy on the other hand has been much researched and various explanations have been adduced about what is cause and what is effect. Here, we note that there are quite a few countries that have reached a rather high level of human development due to economic advances in GDP but they have not established a full rule of law regime, comprising of both rule of law I and rule of law II. Finally, one may enquire into the empirical association between rule of law I and rule of law II. It holds generally that countries that institutionalise the constitutional state also respects judicial independence, but the converse does not hold. Some countries only honour one form of rule of law, namely legality. Numerous countries have neither rule of law I nor rule of law II.

\section{GOOD GOVERNANCE WITH THE WORLD BANK PROJECT}

The concept of good governance has no standard definition in the dictionaries. Instead, I will rely upon the approach of the World Bank Project to governance. The World Bank (WB) states: "Governance consists of the traditions and institutions by which authority in a country is exercised. This includes the process by which governments are selected, monitored and replaced; the capacity of the government to effectively formulate and implement sound policies; and the respect of citizens and the state for the institutions that govern economic and social interactions among them." (http://info.worldbank.org/governance/wgi/index.asp) 
The World Bank's Worldwide Governance project, mapping good or bad governance around the globe during the last decade, identifies six dimensions in of the concept introduced in the quotation above.

In the World Bank Governance project, one encounters the following definition of "rule of law": Rule of Law (RL) $=$

capturing perceptions of the extent to which agents have confidence in and abide by the rules of society, and in particular the quality of contract enforcement, property rights, the police, and the courts, as well as the likelihood of crime and violence (Kaufmann, Kraay, and Mastruzzi, 2010: 4).

Rule of law (RL) is explicitly separated from voice and accountability (VA), which is defined as follows in the World Bank project thusly:

Voice and Accountability (VA) = capturing perceptions of the extent to which a country's citizens are able to participate in selecting their government, as well as freedom of expression, freedom of association, and a free media (Kaufmann, Kraay, and Mastruzzi, 2010: 4).

The WB Governance project suggests four additional dimensions of good governance (political stability, government effectiveness, regulatory quality, and the control of corruption). The World Bank Governance project employs a host of indicators in order to measure the occurrence of rule of law RL around the globe, which results in a scale from -3 to +3 .

In a constitutional democracy, there is a combination of both rule of law (RL) and voice and accountability (VA). But rule of law was conceived already in the Ancient and medieval periods, whereas Western type democracy belongs to the $20^{\text {th }}$ century. Thus, I will separate between a narrow concept of role of law (RL), corresponding to the World Bank's terminology, and rule of law in a broad concept, as including voice and accountability (VA). Several countries have or may introduce rule of law I without accepting rule of law II, i.e. party competitive democracy.

Rule of law principles offer mechanisms that restrain behaviour. We distinguish between rule of law in a narrow sense (legality, due process) - RULE OF LAW I - and in a broad sense - RULE OF LAW II (constitutional democracy). Some countries practice only rule of law I, whereas other countries harbour both mechanisms. A few countries have neither rule of law I or rule of law II, especially failed or rogue states or states in anarchy or anomie. Figure 1 shows the overall global picture with Rule of Law II on the x-axis (voice and accountability) and Rule of Law I on the y-axis (legality and judicial autonomy). 
Figure 1. Rule of Law I (rlest08) and Rule of Law II (vaest08)

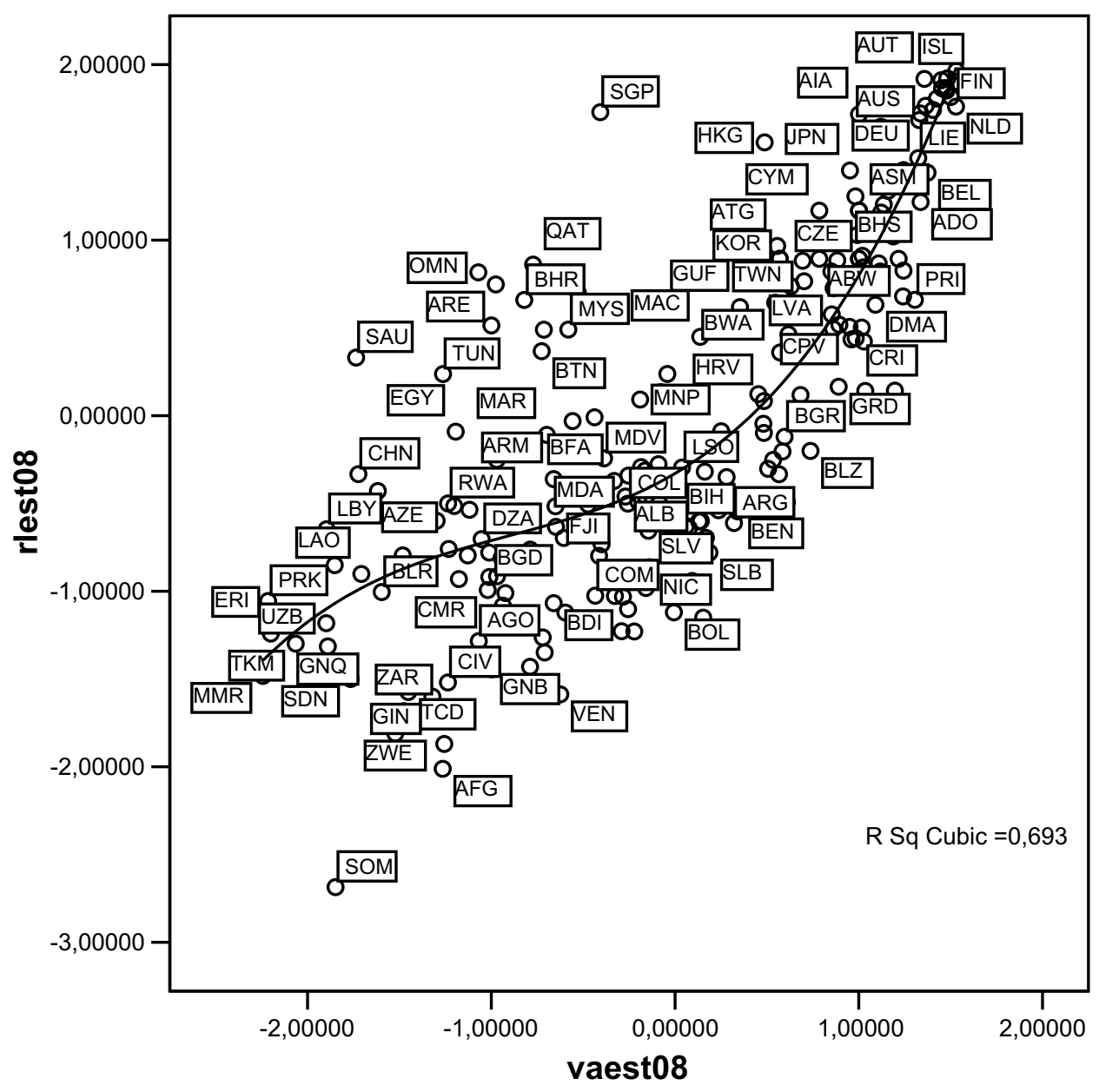

Source: Governance Matters 2009. Worldwide Governance Indicators 1996-2008: vaest08, rlest08.

On may divide Figure 1 into four boxes with the countries scoring negative on rule of law I and rule of law II in the left bottom box. They are mostly African and Asian countries. A few African and Asian states are to be found in the upper left box, meaning they score zero or medium positive on rule of law I but negative on rule of law II. Why is this global pattern so strong and persistent? For the populations in these African and Asian countries with a lack of rule of law, especially rule of law I (legal integrity and judicial autonomy), it is a dismal predicament, especially when analysed from a principal-agent perspective

\section{PRINCIPAL-AGENT MODELLING}

The principal-agent problem in politics and public administration refers to how the people as principal - demos - empower the political leaders and their bureaucrats to govern the country. The principal-agent contract consists of promises about what these agents will do as well as what they may expect in remuneration. The mutual understanding between the principal and the agents - political consideration - tend to become institutionalised. Thus, constitutional and administrative law and praxis makes up political consideration.

Rule of law is the regime that offers the best guarantee against political agents dominating the principal, or even worse, exploiting the principal. It is a question of constraining agents, i.e. the principal would want the political agents to be powerful enough to safeguard the state or nation, but he or she would also want to constrain the agents so that abuse of power becomes 
less likely, such as embezzlement of public money or torture and sudden disappearances of opponents.

However, one must make a distinction between rule of law on the one hand and democracy on the other hand. Countries that are not likely to endorse Western style democracy may still cherish rule of law. Let us start by mapping the spread of rule of law in Africa and Asia by comparative scores and then interpret the findings in terms of more often used principal-agent framework from advanced game theory.

The principal-agent framework has enjoyed far reaching success in modelling interaction between persons where one works for the other. This interaction is to be found in many settings, such as agriculture, health care, insurance and client-lawyer (Rees, 1985: Laffont and Martimort, 2002). As a matter of fact, the principal-agent problematic is inherent in any employment relationship where one person works for another, who pays this person by means of the value of the output.

Whenever people contract with others about getting something done, there arise the typical principal-agent questions:

$\circ$ What is the quid pro quo between the principal and the agent?

- How can the principal check the agent with regard to their agreement?

$\circ$ Who benefits the most from the interaction between principal and agent?

These questions concerning principal-agent interacting arise whenever there is a long-term contract between two groups of people, involving the delivery of an output against remuneration as well as a time span between the making of the contract and the ending of the relationship with the delivery of the output. One finds this type of interaction in the clientlawyer relationship in the legal context, in the owner-tenant interaction in sharecropping as well as in the asset holder-broker relation in financial markets.

\section{Agents and demos}

The agents - politicians and public officials - and the principal - demos - are the two key components of political interaction that run through all political systems, whatever their nature may be. The problem of institutionalising the polity originates in this opposition between agents and the principal.

The strength of the principal-agent model is that it bridges rational choice and neoinstitutionalism, as its model takes into account three basic elements in interaction, namely rules, incentives and information besides underlining reciprocity. The model is open to the occurrence of opportunistic behaviour, even with guile. When a player has information advantage, then this will be transformed into some form of cash premium. The principal may diminish the information advantage of the agent as specialists by framing the rules of the game such that he/she may have the option of counter-play or replay as well as complaint and judicial redress.

\section{Constitutional government}

Constitutional government embodies institutions or rules that constrain those active in domestic or international politics today. Thus, the meaning of "constitution" is a set of principles or rules that constrain rulers, politicians, governments or states. But there can be constitutional government without Western democracy, based upon competitive elections among political parties. 
The spread of rule of law II (democracy) seems to be culture bound, as countries with an Islamic (The Koran as constitution) or Buddhist tradition (Asian values) hesitate to adopt fully Western democracy as competitive party government. However, the introduction and enforcement of rule of law I is an entirely different matter. Due process of law is relevant for all states in the world. Where it is lacking, we find arbitrary government, embezzlement of public money and the unpredictable seizure and violent treatment of persons.

Consider Figure 2, constructed with the WB Governance Project data. It links the control of corruption on the $y$-axis - state transparency - with the rule of law I on the x-axis.

Figure 2. Rule of Law I and Tranparency

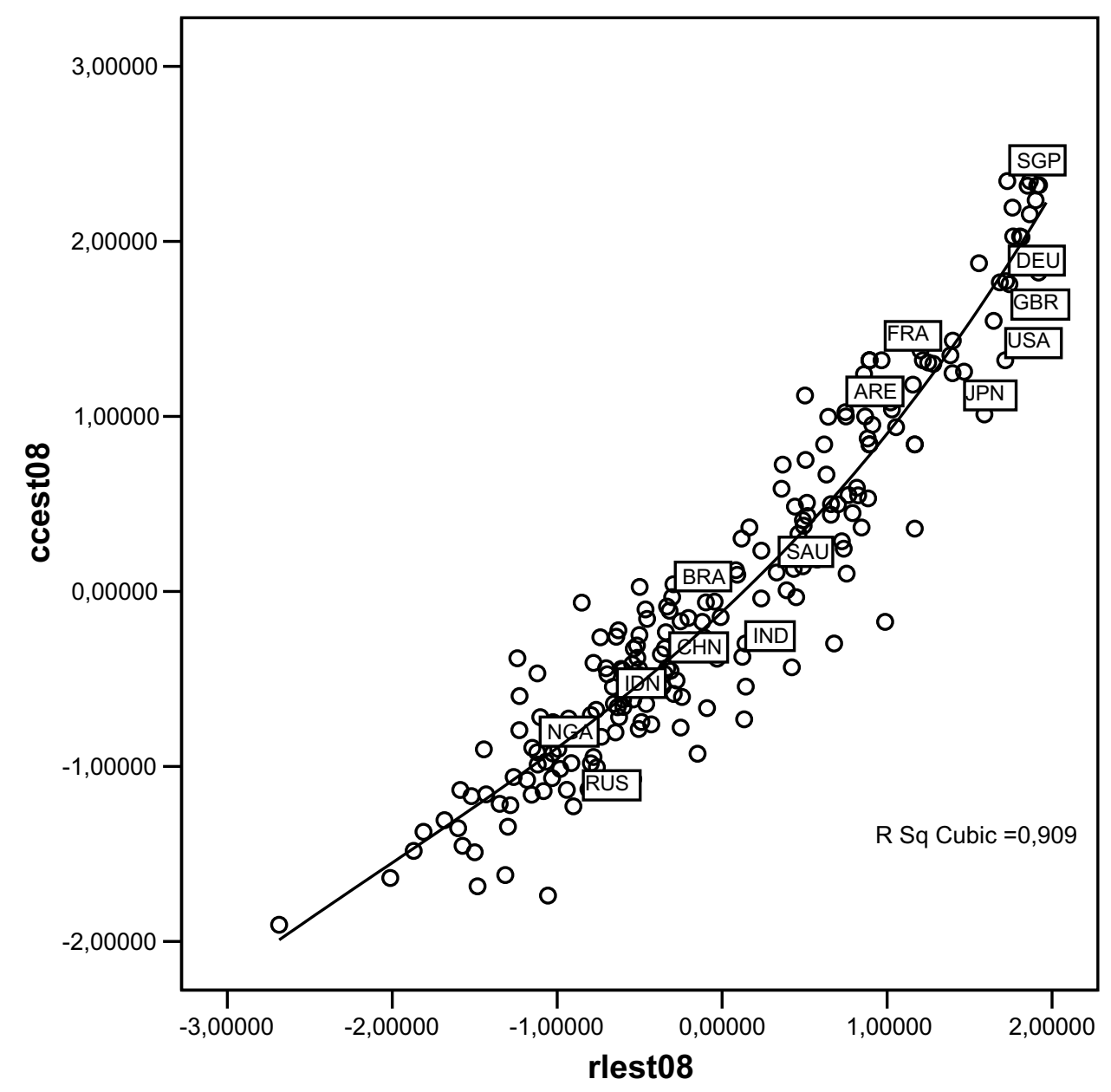

Source: Governance Matters 2009. Worldwide Governance Indicators 1996-2008: rlest08, ccest08.

Rule of law I can be promoted by institutional policy-making by the political elites in a country. A key institution is the Ombudsman, checking the legality of public administration. Rule of law I is highly relevant for the state, also the countries that are non-democracies: military government, charismatic rule, kingdoms, sultanates, failed states, one-party states. It is the best antidote against much long-lived presidents (Burkina Faso, Malawi), arbitrary court rulings (Egypt, China), kleptocracy (Mobutu, Ben Ali), torture (Idi Amin), terrorist attacks (Kenya, Pakistan), civil war (Iraq, Syria), violent civil protests (Bangladesh, Thailand), patronage or favouritism (Saud family, Jacob Suma) and religious judicialisation (Iran, Afghanistan). 


\section{WHY RULE OF LAW: WHAT IS THE BASIC RATIONALE?}

There is a form of interaction that tends to be long-term between individuals, which involves a hiatus between the agreement about what is to be done against remuneration (ex ante) and the later in time fulfilment of this contract (ex post). This time interval, lasting often more than several months or years, sets up the monitoring problem: Has the agreement been fulfilled in accordance with the considerations when the contract was made? This type of interaction does not take place in the various market forms, but constitutes a problem of analysis in itself (Arrow, 1963). The more this special type of contracting was analysed, between a principal asking for a service or job on the one hand and a set of knowable agents delivering this service or job on a long-term contract, the more often it was found in various important sectors (Ross, 1973; Grossman and Hart, 1983; Sappington, 1991; White, 1992; Ackere, 1993; Althaus, 1997). What came to the known as "the principal's problem" was found in lengthy interactions within legal affairs, psychiatry, stock-market trading and agricultural production (sharecropping).

Two basic aspects of long-term contracting are transaction costs and asymmetric information, which never entered in the standard assumptions of the neo-classical decision model in mainstream economics. Since the agent(s) is supposed have much more knowledge about the service or job to be done, the principal needs to diminish this advantage, but without running up too heavy transaction costs, through costly monitoring or litigation. The agent(s) wants remuneration, which has to come from the value of the service or job delivered. Thus, there is both cooperation and conflict.

The theory of transaction costs stimulated this way of looking at long-term contracting (Rao, 2002). It was also furthered by insights into the nature of institutions, where rules could be employed to prop up the position of the principal (Furubotn and Richter, 2005; Weingast, 1989; Persson and Tabellini, 2003). Now, rule of law is nothing less than the regime that hands down institutions that counter-act agent opportunism, bolstering the principal.

\section{Opportunism of Politicians and Bureaucrats}

Political agents are no different from any other human beings. They are driven by the same mixture of egoism and altruism as the average person. Sometimes political agents may be completely obsessed by protecting their own self-interests, as with cruel personalities like Genghis-Khan, Tamerlane, Hitler and Stalin. Sometimes political agents display great generosity and forgiveness towards their opponents, like Gandhi and Mandela. But on average political agents - politicians and public officials - would be self-seeking, often with guile - the opportunism assumption.

The implications of assuming opportunism on the part of agents are strengthened in terms of importance when one adds the basic fact about long-term interaction of the principal-agent type, namely asymmetric information. It is the agent who delivers the output who knows the most about all things relevant to the interaction. And the agent will use this information advantage to capture a rent, or a set of benefits.

Strategy is a pervasive trait of human interaction, both in the micro setting and in the macro setting. Taking strategic considerations into account goes well in hand with opportunism and asymmetric information. The same applies to tactics. What, then, is the basic issue of contention in the principal-agent interaction? Answer: the division of advantages, given a certain size of the mutual gains to be had.

The state helps the population produce an output, a set of goods and services, to be denoted here with " $\mathrm{V}$ ", meaning value. By providing peace and stability, the population may engage in 
productive labour, resulting in an output of increasing value year after year. The political agents will claim a part of this value $\mathrm{V}$ for their contributions. It is the principal who ultimately has to pay the agents out of the total value $\mathrm{V}$ in society.

The agreement about what the agents are to contribute with as well as what they are to be paid may be only a tacit one. It may not even be a voluntary one, as the political agents may force the principal to accept an agreement by the employment of force.

Two things are of great concern to the principal:

1. The maximisation of $\mathrm{V}$ : If the political agents act in such a manner as to reduce $\mathrm{V}$, then this is not in the interest of the principal.

2. Reasonable agent remuneration R: If the agents manage to capture a considerable portion of $\mathrm{V}$ for themselves, then that would be counterproductive to the principal.

It follows from these two principles that principals would be very unhappy with a situation where their political agents contribute to a low output $\mathrm{V}$, while at the same time providing them with a considerable share of $\mathrm{V}$ by maximising $\mathrm{R}$.

What is included in the output V? One may confine $V$ to the set of public or semi-public goods. The country contracts with a set of agents in order to protect $V$, but the country must remunerate the agents (R) from $V$. How can the country select and monitor its agents so that $V$ is maximised, given the constraint that the set of agents must be compensated for their effort $\mathrm{R}$, from $\mathrm{V}$ ? One may offer a most comprehensive definition of $\mathrm{R}$, denoting both tangible assets and intangible ones? R includes all things that are valuable: goods, premises, services, assets, perks, prestige, esteem, etc.

The interaction between political leaders and the population is omnipresent. Whatever the leaders are called and whichever rules apply for their behaviour, human societies have not been leaderless. Even among groups with a highly egalitarian culture, political leaders somehow emerge. This sets up the principal-agent problematic inherent in the state.

When two people or sets of people interact, they may arrive at a mutual understanding of the terms of interaction. These expectations may be enshrined in a contract, written or verbal. Yet, even when the expectations governing the interaction between the political agents and the principal are not codified somehow, there is still consideration.

Consideration is at the core of human exchange and contracting: Something of value is given for getting something from another person. Consideration is the inducement, price or motive that causes a party to enter into an agreement or contract. In politics, the leaders receive ample consideration for governing the country. They take a part of total value $\mathrm{V}$ for their needs. And they are expected to deliver services to the political club, first and foremost maintain the peace, deliver public goods and enhance the GDP.

Since the consideration must be some benefit to the party by whom the promise is made, or to a third person at his instance, or some detriment sustained at the instance of the party promising by the party in whose favour the promise is made, politics is replete with consideration. The agents of the state employ a variety of techniques to raise value to themselves as consideration for their governance activities. 


\section{Political Monopoly}

The external costs to the state may be very high, if there is political monopoly. What the principal would not want to have, all other tings equal, is a situation where the political agents not only take a huge remuneration $\mathrm{R}$ for their work but also accomplish mediocre or straightforward disastrous outcomes, reducing the value of society $\mathrm{V}$. In the principal-agent literature, excessive remuneration on the part of the agent is referred to as "rent-seeking", whereas the failure of the agents to deliver on what they have promised is called "dissonant" actions. The important point here is that political agents may disappoint their principal on two grounds: (1) Dissipation of value V, meaning underperformance as measured by outcomes; (2) Looting, i.e. engaging in excessive remuneration $\mathrm{R}$.

A virtue of the principal-agent perspective is that it alerts people to the possibility of largescale looting in politics and public administration. The worst case scenario for the principal is the combination of bad outcomes in politics and excessive remuneration for agents responsible for the results. This happens often when there is looting.

"Looting" refers to any form of taking of value that amounts to an un-proportional compensation in relation to the effort exerted. It may be illegal, as when soldiers go on a rampage. But political looting is often more refined than populist looting when law and order breaks down. The appropriation of the resources of the administrative apparatus ("slack") is a typical form of political looting, much emphasized by Weber for his comparative institutional analyses (Weber, 1978). The concept of political looting is broader than the notion of corruption or embezzlement, which are strictly illegal phenomena.

Looting may occur with or without value dissipation. Political agents may successfully claim a huge portion of the value in society without at the same time reducing the total size of value. In many Third World countries, political looting goes hand in hand with value dissipation though. An extreme case is that of present day Zimbabwe, which country according to its president "is mine".

Sophisticated forms of looting may occur in constitutional democracy, as when the executive allows itself to be surrounded by vast staff of advisors, experts and the like. Or political agents in the legislature manage to provide themselves with excessive budgets and perks. The fact that corruption allegation is an almost constant theme in public debate indicates how sensitive the principal is to the risk of looting. One form of political looting is of course nepotism or favouritism with regard to family members or cliques of friends when conducted by a president or premier for instance. Petty forms of looting involve negligence about the line of separation between private and public expenditures.

The rule of law regime is highly aware of the risk of looting, offering restraining rules about taxation, budgeting and financial accountability. It also aims at counteracting the dissipation of social value through representation, election and re-election. The dissipation of value is a problem of aggregation in society (size of the cake), whereas the risk of political looting presents a distributional problem (who gets what).

\section{Value Dissipation}

The constant focus of policy-makers upon economic growth shows how aware the principal is today about the risk of value dissipation. The population worries not only about various forms of looting but also about the risk of unfortunate or disastrous policy-making that reduce aggregate income or wealth. A set of political agents may be extremely costly to the country because they are incompetent although honest. Political consideration as defining the quid pro 
quo relation underneath political leadership would comprise some mechanism for replacing one set of agents with another, especially in a rule of law regime.

There is the possibility of a dramatic effect from the combination of looting and dissipation of value, like for instance as matters now stand in countries like Myanmar, Zimbabwe and North Korea. One should not, however, assume that the risk of value dissipation is unique to Third World countries. On the contrary, value dissipation occurs also in First World countries, where the 2003 American led invasion of Iraq offers a telling example, resulting in so huge costs human and economic - and so little. And even a country like the UK with its rule of law tradition does not appear to be immune from various looting strategies on the part of parliamentarians, definitely immoral but not always illegal. Consider Figure 3 depicting the relationship between rule of law I and the level of human development.

Figure 3. Human Development Index 2008 and Rule of Law I

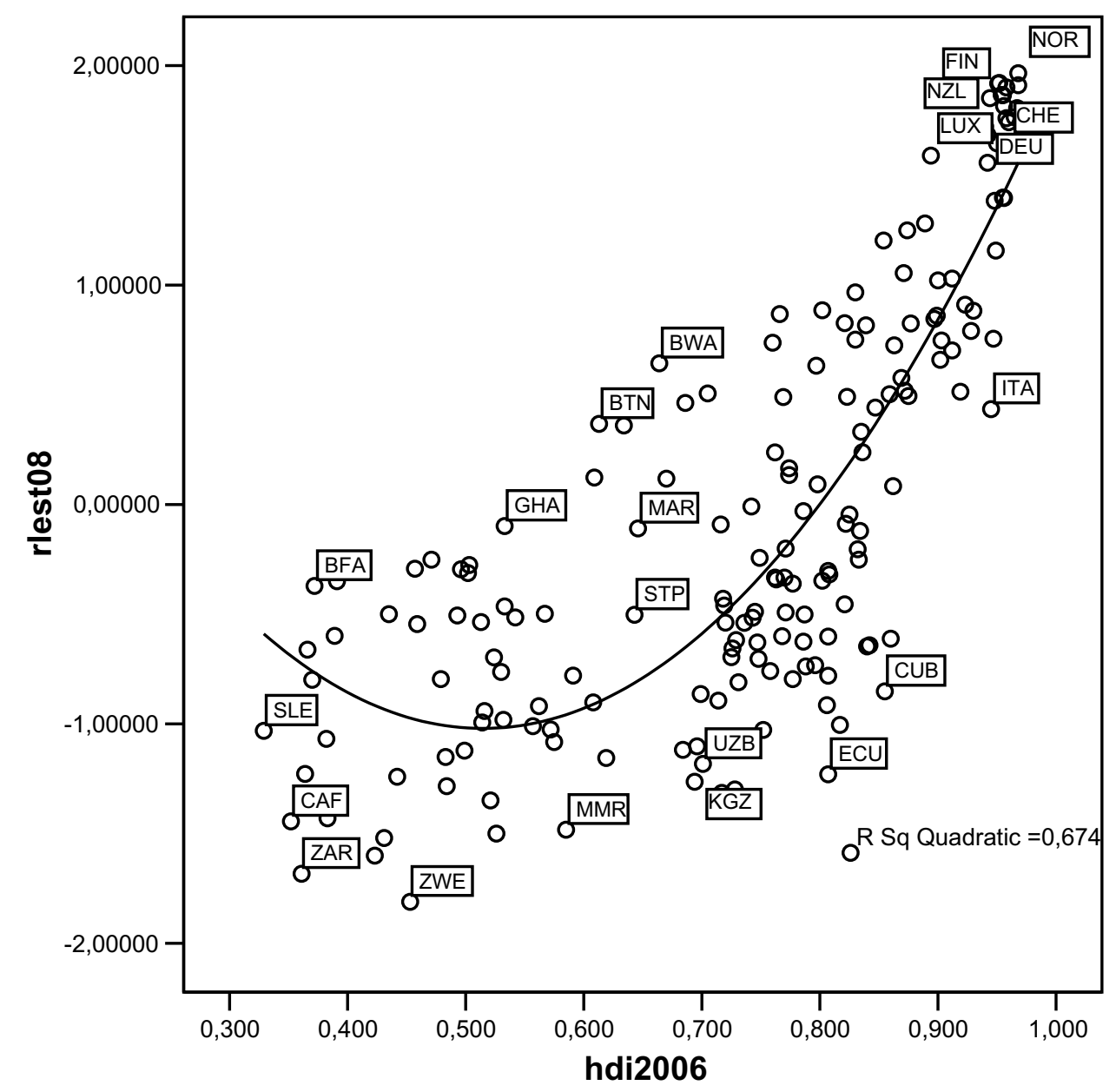

Sources: Governance Matters 2009. Worldwide Governance Indicators 1996-2008: RLEST 2008; UNDP (2008): HDI 2006.

The theory of good governance entails that a government adhering to rule of law precepts will tend to be more successful in enhancing socio-economic development than a government that fails to respect them. Thus, economic activity will be stimulated by legal predictability, the protection of property, and the autonomy of judges when testing cases for assumed violations of law (Cooter and Ulen, 2010). 


\section{Constraining politics and administration}

Rule of law institutions constrain the political agents - politicians at various levels of governments, political parties, rulers, bureaucrats, agencies, etc. - to the advantage of the demos, i.e. the population in a country. Only rule of law institutions can restrain political agents from engaging in opportunistic behaviour, like e.g. corruption, favouritism, embezzlement or patronage.

Within a country normally the constitution outlines a set of constraints upon the political agents, when it is enforced. Internationally, states accept to participate in regional and international organisations that also may restrain the political agents. The process of globalisation has reinforced the regional and international bodies, constraining more and more the states of the world.

One may view the structure of political agents as a nexus of principal-agent relationships. Thus, groups choose their political parties, who when elected to the national assembly in turn select government officials. The population as the principal may wish to have a set of different types of agents, confronting and controlling each other - separation of powers. Competition among agents in elections is one mechanism for restraining political agents, counter-veiling agents like judges constituting another mechanism.

The principal would, one may imagine, support the recruiting of agents in the regional and international bodies, as they offer further restrictions upon the governments of states. Public international law offers some important protections for the country population against abuse of power by their own governments.

The idea of a principal-agent relationship is simple when one person hires another to do work for him against compensation in a contract with a long-term duration - consideration. Typical of political institutionalisation is that there are several principal-agent relationships and they are not all of the same kind.

First, one may distinguish between executive, legislative and judicial agents - the classical doctrine of tries political in constitutionalism. The interaction between executive and legislative agents may be structured alternatively, like in parliamentarism or presidentialism. What is crucial with the judiciary, whether structured as in the Common Law tradition or as in the Civil Law tradition, is the political independence of the judges from the executive and legislative agents.

Second, a state may be organised on a territorial basis with communes, regions and the national government under alternative institutional arrangements. With federalism, there is a complete replica of the trias politica at each level in the complex system, each province being organised as a state. In a unitary state, the nation-state prevails over the regional and local governments in a single dispensation.

The principal of the state - the citizenry or population - club may fear two kinds of external costs, namely the costs imposed by intruders from outside or troublemakers from inside on the one hand, as well as the costs stemming from the actions of the political agents. The principal would be willing to empower the political club in order to reduce the first type of cost. But strengthening the political club leads to the risk that the political agents become so powerful that they abuse the strength of the state for their aggrandizement. 
The domination of the agents over the principal may take many forms in politics. Most of them involve political monopoly, meaning that a subset of agents eliminate all other contending agents. Political monopoly may take a few institutional expressions: a) Hereditary monarchy; b) Gerontocracy, c) Aristocracy, d) Racial or ethnic domination; and e) the one-party state.

Political monopoly allows the agents to engage in looting, meaning that the agents take a huge part of the total value $\mathrm{V}$ in society for covering their own needs. Looting is an agent strategy that may take different forms. One may point at the revenue system of the Mughal emperors in India, which degenerated slowly into oppressive forms, impoverishing the population, as different agents one after the other squeezed out their "bonuses" from the peasants' V (Keay, 2001). Looting as e.g. tax farming or sharecropping definitely leads to the dissipation of value also in Imperial China (Keay, 2008) and in the later Ottoman Empire (Darling, 1996: Inalcik et al, 1997).

A third form of agent domination is when agents ravage the country, rendering havoc and promoting anarchy. In civil war and anomie, opposing subsets of agents fight each other, while making the life of ordinary people miserable and often short. Civil war entails that the political club no longer exists, or operates in accordance with the original political consideration. It is a marginal case of agent domination, but it is not infrequent.

The mechanism of political monopoly involves exclusion, perpetuation and concentration. Thus, only one subset of agents is tolerated. This subset attempts to prolong its grip on power using various strategies. Finally, advantages - economic or other - are concentrated in this subset of agents.

\section{THIN OR THICK CONSTITUTIONALISM}

A constitutional state affords two kinds of mechanisms that enhance stability in political decision-making, one creating so-called immunities or rights that cannot be changed and the other introducing inertia in the decision-making processes. Immunities and so-called veto players would reduce the consequences of cycling, strategic voting and log-rolling. The critical question in relation to the constitutional state is not whether immunities and veto players per se are acceptable, but how much of these two entities are recommendable? Given the extent to which a state entrenches immunities and veto players, one may distinguish between thin constitutionalism versus thick constitutionalism. In a strong constitutional state there would be several immunities, surrounding in particular private property. In addition, there would be a constitution institutionalized as a Lex Superior, which would be difficult to change and which would be protected by strong judicial review either by a supreme court or a special constitutional court. Would not such a strong constitutional state set up too many barriers for political decision-making? In a thin constitutional state, there would be less of immunities and not much of constitutional inertia in combination with only weak judicial review. Such a weak constitutional state would safeguard the classical negative liberties by designating them freedom of thought, religion and association with the possible exception of private property, which would only be regulated by ordinary statute law. There would be constitutional inertia, but not in the form of qualified majority rules and the legal control of public administration would be important but judicial review would not take the form of a power of a court to invalidate legislation. The problem with a thick constitutional state is that it may bolster the status quo to such an extent that democracy is hurt. These mechanisms that thick constitutionalism involve - immunities, qualified majorities, judicial review - all come into conflict with desirable properties identified above in relation to the making of social decisions: neutrality, anonymity and monotonicity or positive responsiveness. Ultimately, strong constitutionalism runs into conflict 13 with the egalitarian stand in the concept of democracy, 
viz that any alternative should be relevant for social decision, that each and every person should have the same say. A thick constitutional state may enhance political stability but be difficult to bring into agreement with the notion of populist democracy (Tsebelis, 2002). There would simply be too many immunities and too much of inertia for democracy to be able to allow the people to rule. However, it is difficult to see how a thin constitutional state could present a threat to democratic institutions. On the contrary, the institutions of a thin constitutional state could complement the institutions of a democratic state by making social decisions more stable. A constitutional state may be erected by means of a minimum set of institutions or a maximum set. In the minimum set up there would have to be institutions that safeguard the following: (1) legality; (2) representation; (3) separation of powers; (4) control of the use of public competencies and the possibility of remedies. It is difficult to understand that such a minimum set of institutions would threaten democracy. When there is a maximum set of institutions in a constitutional state involving numerous checks and balances, then there is a potential collision no doubt.

\section{Institutional set-ups}

One of the key issues in neo-institutionalist research is the comparison between two basic executive models: parliamentarism with the Premier and presidentialism with the President. Which executive model is to be preferred or performs the best? Examining data on the advantages or disadvantages of alternative structuring of the executive, one is confronted by the problematic of the presidential regime. It comes in several forms: pure presidentialism, mixed presidentialism and formal presidentialism. In the empirical enquiry below, pure and mixed presidentialism is displayed against rule of law I and rule of law II, with the following scoring: $0=$ parliamentarism, $1=$ mixed presidentialism, and $2=$ pure presidentialism. Formal presidentialism as in some parliamentary regimes or as in the Communist dictatorships will not be included in this enquiry. Also in this somewhat different classification of executives, one receives the finding that pure and strong presidentialism tends to be a negative for rule of law I or II.

Election Techniques: I would be inclined to argue that multi-partism is better than two-partism from the standpoint of principal-agent theory, but it is not easy to prove. In general, having several agents working in the interests of the principal is a conclusion from this theory. However, in a two-party system changes in government tend to be more clearcut and effective than in a multi-party system. The danger with a two-party system is that it develops into a oneparty system in disguise. And the main disadvantage of the multipartism is the risk of complete fragmentation of the electorate with more than 10 parties getting seats in the national assembly, creating problems to form a stable government. The distinction between twopartism and multi-partism is closely connected with electoral institutions, although not in a perfect manner. The effective number of parties is lower with majoritarian election formulas (e.g. plurality, run-offs and alternative vote) than with PR schemes (e.g. D'Hondt, St Lague, STV).

It seems that the excellent performance of the institutions of the Washington model is more of an American exception than the general rule. Presidentialism and a majoritarian election formula tend to be negatively related to both kinds of rule of law (I and II). How, then, about a federal dispensation for government? State Format Federalism in a narrow sense is an institutional theory about the structure of any state, democratic or authoritarian. Thus, India and Switzerland are federal but so are the United Arab Emirates and Pakistan. Federalism in a broad meaning is an institutional theory about constitutional democracy, claiming that the federal dispensation works better than a unitary for all constitutional democracies. It is easy to mix up federalism I with federalism II above. Here we only deal with federalism I. Does a mere 
federal dispensation enhance the probability of rule of law? In a federal state format the provinces would ideally constiute states with a constitutional framework, they are represented in a federal chamber in the capital and they engage in legislation supervised nationally by a constitutional court or supreme court. Why would such a dispensation promote rule of law better than the simple unitary state format?

Federalism scores better than unitary states on both judicial independence (rule of law I) and democratic constitutionalism (rule of law II). But they also show that this is mainly due to the low number of federal state and the high number of unitary states. Empirically, federalism has only a weak relationship to judicial independence or constitutional democracy. This comes as no surprise as several unitary countries are deeply committed to the autonomy of judges. The next piece of evidence concerning federalism and rule of law shows the lack of a strong relationship between this state format and constitutionalism. Again, this was to be expected, given that federalism is defined narrowly as a mere state format that is just a self-designation by the country in question (Kavalski, and Zolkos, 2008).

Legal Review: The legal system in some countries offers the ordinary courts or a special constitutional court has the privilege of testing the constitutionality of the laws of the legislative assembly or the acts of the executive. This form of political judicilisation - judicial review - is to be found in all countries that emulated the American constitutional tradition (supreme court) as well as in European or Asian 18 countries that adopted the Kelsen model of a constitutional guardian (constitutional court). Although legal review when exercised properly tends to result in spectacular decisions with great political relevance, one may still ask whether legal review matters generally speaking. Countries may endorse judicial review in its written constitution but fail miserably to employment it in the real constitution. Again, the lack of any clear association between legal review and rule of law I or rule of law II respectively is not difficult to explain. On the one hand, also several countries that have institutionalised a profound respect for judicial independence and the constitutional state reject the relevance of legal review. This is most explicit in countries adhering to the Westminster legacy, in which judges apply the law but do not make it. On the other hand, some countries that adhere to legal review in their constitutional documents have a shaky record in achieving the institutionalisation of either judicial independence or the constitutional state in general. Thin constitutionalism may actually perform better than strong constitutionalism, especially when combined with the Ombudsman institution.

\section{Ombudsman}

In thin constitutionalism, there is less emphasis upon veto players like for instance the Supreme Court or the Constitutional Court. In stead, thin constitutionalism attempts to combine political flexibility with judicial independence and constitutionalism. Typical of thin constitutionalism is the strong position of the Ombudsman, as the legal guarantor of the national assembly.

\section{PRINCIPAL - AGENT INTERACTION}

The principal-agent model is especially valuable when understanding interaction that takes some time to evolve from ex ante to ex post, involving moves and countermoves on the part of both parties. Politicians and bureaucrats versus the population (demos) is an example of such interaction that has a longer time span, as the principal will evaluate whether the agents perform well or not at distinct points in time

When governance is modelled as a principal-agent game, then it is not merely a matter of the interaction between two or more persons. The agent(s) is hired to accomplish an output or 
outcome, to be paid for his/her effort to do so. Here we have the two key foci in a principalagent evaluation of governance: (1) the achievements or V - good or bad performance; (2) the remuneration or $\mathrm{R}$ - high or low.

In the literature, these two aspects - performance and remuneration - are not always kept separate. Thus, one speaks of bad performances when there is only high remuneration like in "corruption" or "rent-seeking". Moreover, bad performance is sometimes equated merely with a failure to live up to promises made. The principal-agent framework is applicable to governance and public administration even when there is no form of embezzlement by the agents, but merely reneging on lofty promises.

A state that runs according to rule of law would satisfy a few conditions that constrain the exercise of political power (Vile, 1967; Tierney, 1982). Rule of law entails that power is be exercised according to the following precepts concerning due legal process and judicial accountability:

1) (1.) Legality (nullum crimen sine lege);

2) (2.) Constitutionality (lex superior);

3) (3.) Rights and duties: negative human rights (habeas corpus);

4) (4.) Judicial independence: complaint, appeal, compensation.

From the rule of law perspective, two unresolved questions are central in political agency, whatever the political regime may be:

(1) What is the proper remuneration of the agents, both salary and perks - R?

(2) Do agents really deliver, i.e. how can agent performance be evaluated systematically in terms of outcome data - V?

The remuneration of political agents, whether in legal or illegal forms, has not been much researched, not even in democracies where information is in principle available. For countries where the state controls such information not much is known, for instance about China or the Gulf monarchies. And political agents may destroy much value V in society - see Meredith on Africa (1997).

\section{ENTRY AND EXIT IN POLITICS}

Membership in a political club is vital to people, as the status of citizen or permanent resident brings many advantages. When countries lack a political club, supplying public or semi-public goods and services, it is in a state of anarchy: where the life of man is solitary, poor, nasty, brutish and short. Political clubs always involves a principal-agent problematic: population against leaders. Two central aspects of this interaction between political elites and ordinary people are the remuneration $\mathrm{R}$ of the leaders for their service to the club as well as the value $\mathrm{V}$ of the output of the leaders to society. Politics is about the entry to and exit from leadership positions as well as the relation between $\mathrm{R}$ and $\mathrm{V}$.

One interpretation of the concept of homo politicus (zoon politicon) with Aristotle is that human beings evolve political organisation in the course of the evolution of civilisation. Political organisation comes in different forms of types of clubs of members and leaders: citystates, empires, oriental despotism, and feudal structure of authority, republics, monarchies, democracies and the authoritarian or totalitarian state. The common core of all forms of political systems is the relationships between leaders on the hand and followers - the members on the other hand (Weber, 1978). From a legal point of view, political clubs may constitute states, but political sociology would speak about political communities, or nations. A neutral term is "government". 
Given that government or the state can be modelled as a political club, government or the state is a collective endeavour by its club members. Political clubs can be small like islands states in the Pacific or Caribbean, and they can include a million or more of people, like India and China. Political clubs are defined by their membership rules that organise persons to participate in the pursuit of collective goals. Persons do not need government for their own individual objectives that they can pursue in markets. Collective goals are lumpy goods and services that require human collaboration to secure on a large scale: infrastructure, education and health care, defence and crime. To allocate these bulky things, the political club amasses resources. Thus, the following question of governance arises: Who is going to decide over the employment of these collective resources? Political club have members as well as leaders.

The entry and exist problematic has been meticulously analysed only in relation to ne social system, namely the market. In the theory of monopoly and anti-trust regulation, great emphasis is placed upon the conditions of entry and exit, as openness of the market to all potential contenders is considered essential to market efficiency, a version of this theme is the "creative destruction" theory of Schumpeter. For losers in market games, there seems to be little comfort except bankruptcy protection? How about the losers in political competition? If the only alternative in exit is personal defeat as bankruptcy, then maybe they will do anything to stay on, once they gained the entry into the political game?

\section{Clubs}

According to Rasmusen (2006), the principal-agent model includes a principal searching to maximise the value $\mathrm{V}$ of some output(s) by means of contracting with a set of agents, remunerating them, $\mathrm{R}$ for their efforts in producing the output. The payments of the agents derive from the value of the output of the agents, meaning that the principal-agent contract must involve considerations covering the ex ante to the ex post stages.

Political clubs are powerful in proportion to the resources they can muster and control. When they are capable of taking action, the entry to leadership of the club becomes attractive. Clubs are stable when the actions and decisions of its leadership are accepted and obeyed by the members. When the likelihood of obeying is considerably reduced, the club risks disintegration or disappearance.

Leadership in political clubs are sought after, because of two things basically:

$\circ \mathrm{R}=$ remuneration from work done for the club;

○ $V=$ influence directly over the value of the output that the club produces as well as indirectly over the entire economy (GDP).

Although this distinction has often been confused, a major institutional development of political clubs is the separation of $\mathrm{R}$ from $\mathrm{V}$, making appropriation of public assets impossible, or at least more difficult.

Both $\mathrm{R}$ and $\mathrm{V}$ are highly important to political elites, as $\mathrm{R}$ may give them a decent standard of living, whereas control over parts of $\mathrm{V}$ presents them with opportunities for rewarding the people who work for them or support them, i.e. the followers of the leaders.

The principal-agent framework has enjoyed far reaching success in modelling interaction between persons where one works for the other. This interaction is to be found in many settings, such as agriculture, health care, insurance and client-lawyer (Ross, 1973; Rees, 1985: Laffont and Martimort, 2002). As a matter of fact, the principal-agent problematic is inherent in any employment relationship where one person works for another, who pays this person by 
means of the value of the output. Whenever people contract with others about getting something done, there arise the typical principal-agent questions:

1) What is the quid pro quo between the principal and the agent?

2) How can the principal check the agent with regard to their agreement - the monitoring problem?

3) Who benefits the most from the interaction between principal and agent - who takes the surplus?

These questions concerning principal-agent interacting arise whenever there is a long-term contract between two groups of people, involving the delivery of an output against remuneration as well as a time span between the making of the contract and the ending of the relationship with the delivery of the output. One finds this type of interaction in the clientlawyer relationship in the legal context, in the owner-tenant interaction in sharecropping as well as in the asset holder-broker relation in financial markets.

In politics, transaction costs are minimised by handing over the responsibility for the tasks of the political club to a set of people, called the leaders, or "agents". The agents provide the members of the political club - the principal - with the chief goods and services of this type of community, when they are successful that is.

The agents and the principal are the two key components of political interaction that run through all political systems, whatever their nature may be. The problem of institutionalising the polity originates in this opposition between agents and the principal while taking transaction costs into account (Barro, 1973; Ferejohn, 1986; Weingast, 1989; Rao, 2002; Besley 2006; Helland and Sörensen, 2009).

When governance is modelled as a principal-agent game, then it is not merely a matter of the interaction between two or more persons. The agent(s) is hired to accomplish an output or outcome, to be paid for his/her effort to do so. Here we have the two key foci in a principalagent evaluation of governance: (1) the achievements or $\mathrm{V}$ - good or bad performance in producing outputs; (2) the remuneration R of the agents or leaders - high or low.

The output of goods and services is the value that governments bring to the affluence of the country, its GDP. It may consist of allocative programs or re-distributive ones. It can be positive, as when government succeeds in harbouring a period of economic growth and a mixture of public services. But it can also be negative, for instance when leaders use part of the country resources to remunerate themselves. Political leaders want access to both $\mathrm{R}$ and $\mathrm{V}$. Thus, entry to the leadership of the political club is a necessity.

\section{Entry}

Entry can be open or closed. Openness of political entry as against closed leadership access is a most determining aspect of a political club in the sense that it is linked with many characteristics of a political club. What counts is de facto open entry, but de jure openness is not merely legal formalism. Constitutional regulation of entry is often a first step towards real openness, but it may also be a façade.

\section{Closed Entry}

Many kinds of restrictions upon open entry into the leadership of a political club are conceivable. In traditional societies, the ascriptive criteria of ethnicity and religion constitute barriers, while in modern societies political party adherence tends to be the major stumbling block, as in authoritarian and totalitarian clubs. In democratic clubs, there is firstly formal 
openness of entry and secondly real openness, to some extent. Finally, we have the clubs of warriors who try to take over leadership if a club. They are characterised by tight relations between leaders, i.e. maximum closeness in often charismatic bounds to one of the leaders.

Thus, openness of political entry is a most important feature of a political club. By means of open entry, old leaders may be challenged by new ones, having a different idea about the objectives of the political club. It is also the means with which new elite may secure its financial basis, providing them with R. One may distinguish between different types of political clubs on the basis of the openness of political entry:

- Closed political clubs: clans, tribes, kingdoms, sultanates, juntas, one-party states, hierocracies;

- Open political clubs: constitutional monarchies, republics, democracies.

Biological heritage or lineage constitutes a powerful mechanism for recruitment in closed political clubs. Closing the political club to the family or the wider clan is a tool to control R and V. Interestingly, one form of entry in Islam was adherence to the family of the prophet, i.e. the clan Quraysh, but it was overrun by oriental despotism, meaning a family dynasty for the ruler who happens to be in power.

The closure of political entry always involves violence, or the threat thereof. Political violence is the use of violence against persons for political reasons, i.e. relating to the goals and means of the political club. In a closed political club, political violence may be employed to back up the sitting leaders. Or it may be resorted to by revolutionary new elite, attempting to crush the established one.

In order to uphold dominance in a closed political club, leaders are willing to engage in all forms of political violence, from stabbing contenders, even children in their entourage "palace politics" - to large scale military manoeuvres, like for instance genocide towards minorities perceived as threats.

Political clubs operating with closed entry are fundamentally instable. The only exception to this generalisation is the set of Gulf monarchies, where tradition, religion, wealth and naked power combine to buttress the ruling elite, although infighting has not been absent, including assassinations.

Closed political clubs in the form of military juntas or one-party regimes display few restrictions upon the use of political violence to control entry, from faked legal proceedings to underground hidden operation, outside the law. In addition to external opposition, closed political clubs face the possibility of secret internal factions, plotting against the ruling elite. Or such perceived, imagined or constructed threats may be employed for ruthless repression inside the ranks of club leadership.

Closed entry provokes resistance from excluded groups, which sometimes may be handled through co-optation on a limit scale. When political violence occurs, it may remove one elite only to be replaced by other elite. Or rebellion may replace closed entry with openness of entry.

Revolutions, especially the great ones, constitute reactions to closed entry. They may result in more of openness of entry, like the American or French revolutions for a time, or they may end in closed entry again, like the Russian and Chinese revolutions. The closed club of Lenin is especially calamitous, as it preserved the tsarist characteristics of the country, to some extent 
even up to today. The second American revolution of Lincoln consolidated the open club, inviting a rapid economic development in contrast to the decline of Russia during totalitarianism.

\section{Open Entry}

The central question about political clubs with open entry concerns how much openness there is. It has often been the case that open entry was restricted to some groups of club members but denied other groups, who sometimes were not even regarded as "members" although living within the borders of the club. Various exclusion criteria have been employed: race. income and wealth, age, religion. social strata. Open entry entices fierce competition, focussing upon the electoral mechanism. Elections in closed political clubs have entirely different functions than channelling competition into peaceful channels. It no doubt requires a structure of institutions.

Yet, open entry is never completely free in the sense that anybody could enter politics just as he or she wishes. The typical manner in which free entry is played out is the competition among the groups of leaders we call "political party".

The political party tends to be the key actor in open entry. Its rationale is to gather individual forces into a collective effort to win the elections, opening the road to the leadership positions. Leadership in a political club offers not only remuneration $\mathrm{R}$ but also some control over the value $\mathrm{V}$ in society.

Political parties are nothing but coalitions among individuals who wish to compete in open entry. Together they stand a better chance of gaining than going along alone. To act as a collective unit, they need some coherence of commitments - the ideology. The party program or platform makes it possible for the coalition of party members to campaign with a reasonably clear message that has some coherence in the views of supporters. On the other hand, the necessity of a political party for competing successfully constitutes a real hindrance for loners who would wish to enter but lacks a party affiliation.

Not even a charismatic person can in open entry alone. Some form of political party is necessary. To distinguish one group of political from another, these coalitions we can "parties" employ a variety of tools: ideology, slogans, labels, logos, etc. The coherence of a party is never 100 per cent, as infighting and factions often occur. Politicians interpret the vocabulary of the party differently.

The prevalence of political parties in open entry implies that party organisations with huge staff and resources enter the basic equation of $\mathrm{R}$ and $\mathrm{V}$. One could argue that the remuneration of the party staff should be the burden of the political elite or its followers, but one often encounters public mechanisms for the reimbursement of the costs of political parties, i.e. their $\mathrm{R}$ is taken from $\mathrm{V}$. The political party may be inclined to use whatever command it has over $\mathrm{V}$ to benefit especially themselves - see the literature on the political business cycle.

Partitocrazia involves a fierce struggle among various elite groups for remuneration and access to leadership position. It may degenerate into infighting to such an extent that the party in question cannot operate adequately. And it may make a political club ungovernable with huge costs for society.

In open entry political cubs, political parties or coalitions among leadership groups compete on the basis of promises and blame. The first strategy is basically what the parties claim they can 
do for the size of V: Higher economic growth; Investments in infrastructure; Improvements in public services; Better control of violence and crime, including terrorism now; More of income and wealth redistribution. Are these promises credible? Could not the leadership of a club result in losses in V? Here is where the logic of political competition comes in. The second strategy is the blame, with a strong call for change. In open entry clubs, political competition should in principle be conducive to the maximisation of $\mathrm{V}$, given a modest $\mathrm{R}$. However, the parties in competition may promise too much and blame unreasonable.

The principle of spoils (spolia) is essential to party government in open entry clubs. By winning an election, the party(ies) may employ state resources (jobs, contracts, assignments, etc.) to remunerate the party leaders for their effort to secure victory. In some countries, the costs of the political parties have been more or less entirely transferred to the state coffers by means of public support for them. Spoils, however, require electoral success.

\section{Exit}

The exit problematic in political club is of great importance, as it reveals essential aspects of the club. Exit can be chaotic or violent on the one hand, as in closed political clubs. Or exist can follow ordinary patterns, like retirement at old age, electoral loss, transition to other roles in the political club, etc. Also the open access political clubs can experience violent forms of exist, as when leaders are assassinated. However, the unpredictable forms of exit are typical of the closed political clubs.

The exit question is how to induce leaders to step down or end their power position. In closed political clubs, all forms of sorties are possible:

- Natural death: Some leaders are so firm in control of events in closed political clubs that only death from age or illness can eliminate them: Stalin, North Korean leaders, Mao, etc;

- Unnatural death: leaders are from time to time murdered, either by a secret plot from their inner circles or through a popular uprising: Ceausescu or Mussolini for instance as examples of the latter:

- Suicide: The most spectacular case is of course that of Adolf Hitler;

- Escape: A convenient form of exit is the chosen exile, like Ben Ali managed when Tunisia turned against his dictatorship;

- Expatriation: When a long-lasting figure is thrown out of his/her position, sending him or her far away constitutes a form of exit: the Shah of Persia would be an example;

- Confinement: the forceful removal of a leader can place him/her in an involuntary confinement within the country. It could be an imposed retirement (Chrustschow) or house arrest, as with Aung San Suu Kyi in Myanmar;

- Imprisonment: in order to exile leaders, they may simply be put in prison (Mubarak) or sent to labour camps, as in Soviet Union and Nazi-Germany.

- Foreign invasion: one cannot neglect the relations to other countries when leaders engage in major atrocities; the falls of Pol Pot or Mobutu are examples.

The unpredictability of exit appears starkly when leaders attempt to stay on longer than agreed upon from the start of their rule. In the grey zone between a closed club or an open club, leaders often gall for the temptation to prolong their period in power, stopping the expected exit from the scene. Many leaders in Africa have secured long time power holdings simply by changing the constitution to allow for unlimited re-election, or having no elections at all (Meredith, 1997). 
Open entry can be undone by several means of the coup d'état, which leads to a shorter or longer closed political club when successful. It may of course fail, sometimes resulting in anarchy.

\section{ASYMMETRIC INFORMATION}

The two essential parameters in a political club is the remuneration $\mathrm{R}$ of the leaders or the political elite as well as the value of the output that the leadership produces, $V$. The information about $\mathrm{R}$ and $\mathrm{V}$ is known to the "agents", but not to the principal - asymmetric information. The members of a political club seldom know the full range of remuneration $\mathrm{R}$ to the political leaders: salaries, pensions, perks, etc. And they get to know the entire situation of the public sector and the whole economy much later than the political elite. In closed political clubs, they may never know much about R and V. In open political clubs, competition among leaders may reduce the amount of asymmetric information about $\mathrm{R}$ and especially $\mathrm{V}$.

Closed political clubs are characterized by massive amounts of asymmetric information. The members of the club know little about the key parameters, $\mathrm{R}$ and $\mathrm{V}$. They are left with assurances, i.e. cheap talk and promise never to be kept. Let me give two drastic examples:

- Nazi-Germany: Hitler made himself the "Fuehrer" of the German people, with the promises of a thousand years Reich, but assembled a great personal fortune by various tricks, only to leave the country with almost no value left at his suicide;

- Sierra Leon became independent from the British with flourishing public and private sectors. The political runs down all value in their chase for "blood diamonds", in order to augment their personal remuneration.

This conflict between $\mathrm{R}$ and $\mathrm{V}$ often occurs in closed political clubs. In Africa after independence, one leader after the other fell for the temptation to increase remuneration $\mathrm{R}$ at the cost of the value of output, through embezzlement, patronage and conspicuous consumption in the entourage of the political elite. As R went up, V stagnated or declined.

The tension between $\mathrm{R}$ and $\mathrm{V}$ are certainly not absent in open political clubs. The full range of $\mathrm{R}$ for political leaders is hardly known even in competitive political clubs, where sometimes leadership creates disastrous outcomes with value losses. One example is the Operation Cobra II (Iraqi Freedom), masterminded with little transparency by president Bush, vice-president Cheney and defence secretary Rumsfeld, resulting in enormous costs for the US, both personnel and resources, while this leader trio somehow ended up as millionaires or billionaires, partly due to relationships with the defence industry.

Yet, open clubs do try to reduce the amount of asymmetric information between leaders and members, partly through competing elites (counter-veiling agents) and partly through the institutions of constitutionalism (Furubotn and Richter, 1991, 2005; Mcllwain, 1958; Neumann, 1986; Vile, 1967; Weingast, 1989).

The state forms a political club, comprising as members the people of the country in question and the political elite as its leaders. Due to transactions, leadership is a necessity for delivering a public sector as well as promoting a thriving private sector (Rao, 2002). In this human organisation, two parameters are central: the remuneration of the political elite $\mathrm{R}$, and the value $\mathrm{V}$ of the output, directly and indirectly that the leadership accomplishes. The parameter $\mathrm{R}$ targets the motivation of leaders, whereas the parameter $\mathrm{V}$ examines their performance.

Approaching the state or government as a political club with leadership and membership entails an analysis of entry and exit in both open and closed political systems. The members 
would prefer low remuneration and high performance, but it does not always occur. On the contrary, in closed or semi-open political clubs, we find excessive remuneration and negative performance. In marginal cases of political exploitation, $\mathrm{R}$ may go as high as $\mathrm{V}$.

How turbulent entry into and exit from political clubs can be appears from the lives of Boukassa (Central African Republic) or Sankara (Burkina Faso) or Nkrumah and Ali and Benazir Butto (Pakistan). Predictable and peaceful avenues of exit from the political club stabilises also the entry into it.

Political instability is not absent from "well-ordered societies" (Rawls), but it takes another from than coup d'etat, embezzlement and states of emergency.

Under any political or in any state, the citizens hire and instruct a set of agents - politicians and officials - to work for them against remuneration to be taken out of the value that the agent contributes to. The agents can put in high effort or low effort, schematically speaking, which has an impact upon the value that is created. The factor "effort" captures all that lead an agent to be either highly or poorly performing. Both parties are assumed to maximise their utility, which for the agents involves compensation for the disutility that high effort imposes upon him/her. Thus, there arises a gaming situation where the agent wants to maximise his/her compensation while the principal wants to maximise the value that the agent helps producing minus the remuneration of the agent. All kinds of solutions to this game are conceivable, depending upon contingencies such as the availability of agents as well as the existence of asymmetric information. In politics, it is the agents who know the most.

The principal would wish to maximise the contribution of the agents to total value and its fair distribution in society, subject to the restriction that the agents need to be remunerated for their effort. Thus, we have the two key equations: (1) Principal: Max total value or income subject to fairness in distribution; and (2) Agent: Max remuneration covering both salary and perquisites. Given perfect information, there is a first best solution to the problem, namely: that the principal installs the most efficient agents, taking (1) and (2) into account. However, given asymmetric information the principal is forced to look for second best solutions that all will involve a better deal for the agents.

In well-ordered societies, the political agents in government operate the set of governance mechanisms that we call "state" (Kelsen, 1961; 1967). It claims sovereignty over its country, but it enters into a web of relationships with other states, governed by the rule of law principles of the international society, namely the so-called public international law (Schwobel, 2011).

A state may be seen as flowing from an agreement among the members about helping each other in securing peace and stability. A body of rules would codify this mutual agreement. A state quickly develops a division of labour between leaders and followers, the subgroup who implements the rules and the subgroup who follow the rules in their behaviour. I will call the followers the "principal" of the political club and the leaders the "agents". Thus, the political club will be modelled as confronted by the principal-agent problematic, comprising inter alia:

- Who are the political agents?

- How are these agents selected?

- Can agent power be laid down formally?

- Are there restraints on the power of the agents? 
In politics, transaction costs are minimised by handing over the responsibility for the tasks of the state to a set of people, called the leaders and their public servants. I will employ the word: "agents". The agents provide the members of the state - the citizenry or the principal - with the chief goods and services of this type of community, when they are successful that is.

\section{ENEMIES OF GOOD GOVERNANCE: ISLAMIC FUNDAMENTALISM}

To understand the $20^{\text {th }}$ century emergence of radical Islamic fundamentalism and its doctrines about Jahiliyyah, Caliphate and Jihad, I will look at the three key personalities behind the ideology or religion of radical Islam movements: Mawdudi, Qutb and Faraj.. Modern Islamic fundamentalism was to a significant extent conceived in the Indian Deobandi movement, from which comes Mawdudi, the Pakistani who inspired the Egyptians: Qutb and Faraj. Their ideas about islamisation, caliphate and jihad constitute the very theoretical legitimation of terrorist events.

When searching for the roots of radical Islam, one cannot bypass Moslem thought in greater India under British rule. Several non-Arab scholars had a profound influence on Islam in Arabia, such as for instance Mawdudi, theorising not only islamisation but also the relevance of the now blossoming Islamic finance. More research is needed to uncover the influence of Muslim thought in India before partition on the Koranic civilisation, especially the Deobandi School.

\section{The Koranic Civilisation}

Radical Islamic fundamentalism has as its main objective to guard the borders of the Koranic civilisation to other religions. Thus, they fear proselytise or mission or conversion campaigns by other religions, the occurrence of apostasy among their own adherents as well as the emergence of schisms or dogmatic splits within their own ranks. All the world religions have reacted with violence against these three threats. Perhaps the posture of Islam is the least open or tolerant in these matters. In the Muslim civilisation marriage, for instance, entails that a women adhering to another religion than Islam converts to the same religion as her husband. It is not difficult to find within the Koran very strong admonitions against proselytism, apostasy and schisms.

Global radical Islamic terrorism has a disastrous impact not only upon the groups targeted but also upon the Muslin countries themselves, setting in motion millions fleeing. In his comparative religion studies, Max Weber put the concept of jihad at the centre of Islam - "a religion of warriors" - in his short historical analysis of the fate of this religion with the Prophet and after him. Several Muslim scholars would sharply deny the correctness of Weber's theory of Islam as a religion of warriors, pointing to the fundamental fact that Islam has just five fundamental duties, which do not include jihad (Huff and Schluchter, 1999).

The new concept of jihad together with the new caliphate, based upon the notion of "pagan ignorance" (jahiliyyah) constitute the core of the radical transformation of Islam in the $20^{\text {th }}$ century by three men. But it has not brought happiness and prosperity to Moslems in general.

\section{"Islamisation"}

Mawdudi, Abul 'Ala' (1903-1979) has been considered as the architect of contemporary Islamic revival. He is considered by many to be the most outstanding Islamic thinker of the $20^{\text {th }}$ century. Mawdudi was influenced by Hasan al-Banna and the Egyptian Muslim Brotherhood. He founded the Jama'at-i-Islami movement in 1941 in the Indian sub-continent, an extremely well-organised association committed to the establishment of an Islamic world order that has 
played an important role in the politics of Pakistan, India, Bangladesh and other South-East Asian countries.

The Muslim community in India responded to the British destruction of the Mogul Empire in 1859 with a seminary in Deobandi in 1866 by former students of the Delhi madrassa, destroyed after the "Revolt of 1857". The new seminary in Deobandi aimed at (1) indoctrinating Muslim youth with Islamic values, and (2) cultivating intense hatred towards the British and all foreign (i.e. non-Islamic) influences. The seminary exposed their students only to the spiritual and philosophical traditions of Islam with the goal of islamisation of state and society in view.

Mawdudi opposed to the secularist nationalist Muslim League led by Jinnah, but on the formation of independent Pakistan he emigrated there, hoping to influence a change from being merely a state for Muslims to an Islamic state. His political involvement and criticism of government policies, as well as his anti-Ahmadiya agitation, led to his imprisonment in 1953, but the death sentence passed was never carried out. Mawdudi saw Islam as threatened by a wave of Westernisation. He criticised the West and the Westernised Muslim elites as degenerate, and he called for a renewal and purification of Islam. He conceived of true Islam as a total comprehensive system and ideology, incorporating society, politics and the state. Mawdudi differentiated sharply between jahiliyyah, which included most contemporary Muslim societies and true Islam. His goal was an ideological Islamic state based on God's sovereignty (hakimiyya) and on Sharia. As an explanation for the decline of Muslim power, Mawdudi concluded that diversity was the culprit: the centuries old practice of interfaith mixing had weakened and watered down Muslim thought and practice in that region of India. In his reinterpretation of Islam, he suggested the following:

(Q1)" Islam is a revolutionary faith that comes to destroy any government made by man. Islam doesn't look for a nation to be in better condition than another nation. Islam doesn't care about the land or who own the land. The goal of Islam is to rule the entire world and submit all of mankind to the faith of Islam. Any nation or power in this world that tries to get in the way of that goal, Islam will fight and destroy."

(Q2)" It [Jamaat-e-Islami] is not a missionary organisation or a body of preachers or evangelists, but an organisation of God's troopers."

(Q3)" In our domain we neither allow any Muslim to change his religion nor allow any other religion to propagate its faith."

(Q4)" Leaves no room of human legislation in an Islamic state, because herein all legislative functions vest in God and the only function left for Muslims lies in their observance of the Godmade law."

Thus, Mawdudi sought to purge Islam of what he looked upon as alien elements. Moreover, the social and political ties with Hindus must be severed. Non-Muslims, for Mawdudi, constituted a threat to Muslims and to Islam and must be contained by restricting their rights. Mawdudi and others founded the Jama'at al-Islami Party in Lahore, Pakistan in 1941. Mawdudi based his call to arms against those who reject Islam on Sura 2: 190-193 from the Koran and on the Hadith, "I have been ordered to fight people (al-nas) until they say 'There is no God but God'. If they say it, they have protected their blood, their wealth from me. Their recompense is with God".

Mawdudi envisioned a particular set of institutions for his ideal Islamic state. An Islamic state will have a President, an elected shura council (consisting only of Muslims who have been 
elected solely by Muslim suffrage), an independent judiciary and a cabinet formed by a Prime Minister. Dhimmis (non-Muslims living under Muslim protection) would have the right to vote in lower-level (i.e. municipal) elections as well as the right to serve on municipal councils and in other local organisations. Mawdudi's objective was jihad until the whole natural universe has been brought under the rule of Islam, as he states, quoted here from ఏihad in Classical and Modern Islam (1996):

(Q5) "Islam wants the whole earth and does not content itself with only a part thereof. It wants and requires the entire inhabited world. It does not want this in order that one nation dominates the earth and monopolizes its sources of wealth, after having taken them away from one or more other nations. Islam requires the earth in order that the human race altogether can enjoy the concept and practical program of human happiness, by means of which God has honoured Islam and put it above the other religions and laws. In order to realize this lofty desire, Islam employs all forces and means that can be employed for bringing about a universal all-embracing revolution sparing no efforts for the achievement of his supreme objective. This far-reaching struggle that continuously exhausts all forces and this employment of all possible means are called Jihad." (Peters, 1996: 128).

The idea of islamisation wreaks havoc in Muslim countries. Since he included the Shias in the set of non-believers, he bears responsibility for the tragic civil war in the Koranic civilisation: (Q6) Mawdudi wrote regarding the Imami Ja'fari Shia, "despite their moderate views (relative to other Shia sects), they are swimming in disbelief like white blood cells in blood or like fish in water."

Mawdudi's thought shows without doubt that non-Arabs have played a major role in Islamic religion and philosophy. His ideas were taken up by two important Arab scholars, thus continuing the very important and dire Deobandi link in present Islam.

\section{"Re-inventing the Caliphate"}

Radical Islamic societies (jama'at) have emerged out of the Muslim Brotherhood founded 1928, but drawing mainly on the thought of its main ideologue, Sayyid Qutb (1906-1966. Qutb's reinterpretation of several key Islamic concepts inspired some to split off from the Brotherhood and use his writings to legitimise violence against the regime. He argued that the existing society and government were not Muslim but rather dominated by "pagan ignorance" (jahiliyyah). The duty of righteous Muslims was to bring about God's sovereignty (hakimmiyya) over society, denounce the unbelief (takfir) of the current national leaders, and carry out a holy struggle (jihad) against them..

Qutb was an Egyptian. The first excerpt below comes from an early work, Social Justice in Islam, which he wrote in 1949. Qutb builds on the Islamic idea of tawheed (the singularity of God and, therefore, of the universe):

(Q1) "So all creation issuing as it does from one absolute, universal, and active Will, forms an all-embracing unity in which each individual part is in harmonious order with the remainder ... Thus, then, all creation is a unity comprising different parts; it has a common origin, a common providence and purpose, because it was produced by a single, absolute, and comprehensive Will ... So the universe cannot be hostile to life, or to man; nor can "Nature" in our modern phrase be held to be antagonistic to man, opposed to him, or striving against him. Rather she is a friend whose purposes are one with those of life and of mankind. And the task of living beings is not to contend with Nature, for they have grown up in her bosom, and she and they together form a part of the single universe which proceeds from the single will." (ocial Justice in Islam)

In Milestones he wrote (Beirut: The Holy Koran Publishing House, 1980: 7-15, 286): 
"If we look at the sources and foundations of modern ways of living, it becomes clear that the whole world is steeped in Jahiliyyah (pagan ignorance of divine guidance), and all the marvellous material comforts and high-level inventions do not diminish this Ignorance. This Jahiliyyah is based on rebellion against God's sovereignty on earth: It transfers to man one of the greatest attributes of God, namely sovereignty, and makes some men lords over others. It is now not in that simple and primitive form of the ancient Jahiliyyah, but takes the form of claiming that the right to create values, to legislate rules of collective behaviour, and to choose any way of life rests with men, without regard to what God has prescribed. The result of this rebellion against the authority of God is the oppression of His creatures."

Qutb rejected all forms of study of religions, or a faculty of religion at Western universities. There is only ONE true religion in the world! His most important achievements to Moslems were his reinterpretation of traditional concepts such as hakimiyya, jahiliyyah and takfir as well as the caliphate, turning them into contemporary revolutionary concepts in his Islamic ideological system.

(Q2) "The Islamic civilisation can take various forms in its material and organisational structure, but the principles and values on which it is based are eternal and unchangeable. These are: the worship of God alone, the foundation of human relationships on the belief in the Unity of God, the supremacy of the humanity of man over material things, the development of human values and the control of animalistic desires, respect for the family, the assumption of the vice regency of God on earth according to His guidance and instruction, and in all affairs of this vice-regency, the rule of God's law (Sharia) and the way of life prescribed by Him."

(Q3) "Humanity will see no tranquillity or accord, no peace, progress or material and spiritual advances without total recourse to Allāh. This, from the Qur'ānic point of view, can mean only one thing: the organisation of all aspects of human life in the Qur'ān. The alternative would be corruption, regression and misery."

"Qutubism" stands for the core of radical Sunni fundamentalism. Qutb is most widely read in the Koranic civilisation - especially his Milestones, but also feared for his violent message. If the idea of islamisation is combined with the notion of the caliphate, the third logical element in the new Islamic terrorism is the re-interpretation of the idea of jihad.

\section{"Offensive Jihad"}

Faraj recruited for his organisation mainly in ahli (independent) mosques in the poor quarters of Cairo, where he delivered Friday sermons. He succeeded in recruiting members of the presidential guard, military intelligence and civil bureaucracy, as well as university students. Faraj's short book Al-Farida al-Gha'iba (The Neglected Duty) had an immense impact on all radical Islamic movements. Following Sadat's assassination, Faraj was executed in 1982.

Whereas Mawdudi was a learned theologian writing massively on The Koran and its interpretations, delivering a long list of books and pamphlets, Faraj only published one text. But its message about jihad added the explosive fuse to the ideas of Mawdudi and Qutb concerning islamisation and unification of religious and secular leadership. Faraj was read among the radicals, in seminaries or in prison, who later went on to set up terrorist groups, in and outside of Egypt. It should be emphasized that the many well-known leaders of these groups had known each other, reading and discussing Qutb and Faraj.

Let me take a few quotations (Q) from Faraj: 
(Q1) "Hence the implementation of Islamic law is incumbent upon the Muslims. Therefore establishing the Islamic State is obligatory upon them because the means by which the obligation is fulfilled becomes obligatory itself. By the same token, if the state can only be established by fighting, then it is compulsory on us to fight. Besides the Muslims were agreed upon the obligation of establishing the Khilaafah, the declaration of which depends on the existence of the core, which is the Islamic State." (page 20)

(Q2) "So fighting in Islam is to raise Allah's word highest, either offensively or defensively. Also, Islam was spread by the sword, but only against the leaders of kufr, who veiled it from reaching the people, and after that no one was forced to embrace it. It is obligatory upon the Muslims to raise their swords against the rulers who are hiding the truth and manifesting falsehood, otherwise the truth will never reach the hearts of the people." (page 51-52)

(Q3) "As for the Muslim lands, the enemy resides in their countries. In fact the enemy is controlling everything. The enemies are these rulers who have snatched the leadership of the Muslims. Thence Jihad against them is fardh 'ayn. Besides, the Islamic Jihad is now in need of the effort of every Muslim. And it should be borne in mind that when Jihad is fardh 'ayn (an individual obligation), it is not required to seek permission from one's parents for the to march forth as scholars said: 'it becomes like praying and fasting."' (page 61)

(Q4) "And what if the scholars of the Salaf saw our scholars of today - except those upon whom Allah has shown Mercy - who have inclined to these tyrants, beautified their actions to them, made fair their murders of the Muslims, the mujahedeen (upholders of Tawheed - Oneness of Allah), weakening their honour by issuing fatwa (legal verdicts) after fatwa to make their thrones firm, and safeguard their kingdoms, by labelling everyone opposed to them as a rebel or khaariji (one of the extreme deviant sect of the khawaarij)?." (p. 108)

"Holy terror" is a term for "holy assassination" and was propagated by Muhammad Abd al Salam Faraj (1954-1982) in his booklet, The Neglected or Absent Duty. Faraj arrived at this jihad (holy war) duty by considering and rejecting non-violent options: participation in benevolent societies; obedience to God, education, abundance of acts of devotion, and occupation with the quest of knowledge; exerting oneself in order to obtain an important position; and democratic options such as engaging in civil liberties such as freedom of speech, the founding of a political party to compete freely with other parties in elections, and the creation of a broad base of support resulting in majority rule. Faraj believed that none of these would lead to the messianic goal of establishing of an Islamic state and ultimately reintroducing the caliphate.

Despite the imprisonment and execution of al-Jihad's leaders following Sadat's assassination, offshoots managed to regroup, declaring jihad against Mubarak's regime. Al-Jihad has continued to be linked to terrorist incidents and outbreaks of communal violence ever since. One wing seems to be loyal to Abbud al-Zammur, one of the original founders, now imprisoned in Egypt. Another wing is called Vanguards of the Conquest or The New Jihad Group led by alQaeda's Ayman al-Zawahiri.

Al-Qaeda, ISIS, Boko Haram, Al Shabaab and the Talibans are Sunni Muslim terrorist groups that consider Shias to be heretics. Osama Bin Laden, al-Zarqawi and al-Zawahiri are close to either Salafi, or Deobandi or Wahhabi brands of Sunni Islam. And the leading thinkers behind modern Islamist movements such as al-Qaeda are all Sunnis: Abul-Ala Mawdudi, Sayyid Qutb and Muhammad Faraj. Their ideas are communicated daily in the schools, madrasas as well as in the religious faculties at universities. 


\section{ISIS replacing Al-Qaeda}

How the ISIS group related to Al Qaeda in Iraq is not fully known. The key person was Abū Muș'ab az-Zarqāwī, who was a leader of the insurgence against the Allied invasion of Iraq. He was not only violently anti-Western but also a sworn enemy of Shiism. He was so bloody in his strategy and tactics - suicide and car bombs - that al-Zawahiri objected, leading to a split from Al Qaeda by az-Zarqāwī. After his death, his main ideas inspired the creation of ISIS. These are the basic ideas of the man called "AMZ":

"i. Remove the aggressor from Iraq. ii. Affirm tawhid, oneness of God among Muslims. iii. Propagate the message that "there is no god but God", to all the countries in which Islam is absent. iv. Wage jihad to liberate Muslim territories from infidels and apostates. v. Fight the taghut ruling Muslim lands. vi. "Establish a wise Caliphate" in which the Sharia rules supreme as it did during the time of Prophet Mohammad. vii. "Spread monotheism on earth, cleanse it of polytheism, to govern according to the laws of God..." (Hashim, 2014)

When Al Qaeda asked AMZ not to target ordinary Moslems, especially Shias, the reply was in the style of future ISIS (Hashim, 2014):

"We did not initiate fighting with them, nor

did we point our slings at them. It was they

who started liquidating the cadres of the

Sunni people, rendering them homeless,

and usurping their mosques and houses."

Thus, AMZ or az-Zarqāwī is much more to be seen as the forerunner of ISIS than al-Zawahiri. But his ideology or religion is the radical Sunni fundamentalism, created by the three: Mawdudi, Qutb and Faraj. Al-Zawahiri wrote several books on Islamic movements, the best known of which is The Bitter Harvest (1991/1992), a critical assessment of the failings of the Muslim Brotherhood. In it, he draws not only on the writings of Qutb to justify murder and terrorism, but prominently references Pakistani Jamaat-i-Islami founder and ideologue Mawdudi on the global mission of Islamic jihad. Global jihad as Mawdudi had prescribed became al-Zawahiri's obsession, However, the ISIS is now calling the shots and they employ the ruthless tactics of AMZ or az-Zarqāwī.

Sunni fanaticism acts like the scourge of Islam for the Middle East, leaving behind immense human and capital destruction. How can ecological policy-making be feasible in so-called "failed states"? The Muslim countries and communities are confronted with handling major environmental resources, like water, forest, sewage, waste, oil and gas, etc. What can a government do if confronted by the "religion of warriors" (Weber). Global ecological coordination will also be hampered by the lack of rule of law in many African and Asian countries - no doubt a legacy of oriental despotism, colonialism and widespread corruption.

\section{ASIA: CHINA, SOUTH EAST ASIA AND THE "STANS"}

Milton Friedman $(2002,2008)$ argued over a long career for the basic idea that capitalism and democracy are closely related. The argument hinges on an intimate connection between economic and political freedom. However, the empirical evidence does not vindicate this argument. The empirical analysis also shows that a set of countries deviates from this interaction, managing to reach both affluence and state firmness without institutionalising rule of law II. Economic freedom and political freedom are not as closely relate as Friedman claimed, especially not in the ASEAN region.

The association between the rule of law I and rule of law II is much weaker than the connection between economic output and rule of lawI, especially in the ASEAN region. Higher levels of 
affluence are yet to result in voice and political accountability in East andSouth East Asia. Most countries in the ASEAN region are at zero or below when it comes to rule of law II.

Sen's (2000) theory that economic development is freedom must beunderstood against the background of his analysis of freedom as capability (Sen 1995). Of course, it is not the sole conception of freedom. In political theory, there is Hobbes' idea of freedom as absence of heteronomy; that is, the lack of constraints imposed on a person by other people or government.

There is also Rousseau's notion of freedom as participation; that is, people are free when they together decide on the laws that restrain their lives. Following these concepts of freedom, it is necessary to focus on the scope and range of rule of law I and II in a country, with human rights as well as voice and accountability being considered. Countries may experience tremendous economic growth without experiencing similar advances in freedom as human rights or freedom as participation in collective choice. As stated above, Sen (2000) maintains that economic progress results in increasing freedom. From a normative point of view, this is a highly acceptable or desirable standpoint. But is it really true in the world we live in? In the ASEAN region, rapid economic development in several countries has not yet resulted in the rule of law. Stunning economic advances in several of the East and South East Asian countries have been accomplished, without resulting in either economic freedom or political freedom. Singapore and Hong Kong are interesting exceptions as these two entrepot entities score high on rule of law I. Only Japan, Taiwan and South Korea come out at a reasonable level on both types of rule of law: rule of law I as judicial autonomy and legal integrity, and rule of law II as voice and political accountability. The typical global association between economic advances and the rule of law is weaker in the ASEAN region than in other regions of the world. This is worthy of more detailed research along the lines indicated in this discussion.

\section{CONCLUSION}

Under any political or in any state, the citizens hire and instruct a set of agents - politicians and officials - to work for them against remuneration to be taken out of the value that the agent contributes to. The agents can put in high effort or low effort, schematically speaking, which has an impact upon the value that is created. The factor "effort" captures all that lead an agent to be either highly or poorly performing. Both parties are assumed to maximise their utility, which for the agents involves compensation for the disutility that high effort imposes upon him/her. Thus, there arises a gaming situation where the agent wants to maximise his/her compensation while the principal wants to maximise the value that the agent helps producing minus the remuneration of the agent. All kinds of solutions to this game are conceivable, depending upon contingencies such as the availability of agents as well as the existence of asymmetric information. In politics, it is the agents who know the most.

The principal would wish to maximise the contribution of the agents to total value and its fair distribution in society, subject to the restriction that the agents need to be remunerated for their effort. Thus, we have the two key equations: (1) Principal: Max total value or income subject to fairness in distribution; and (2) Agent: Max remuneration covering both salary and perquisites. Given perfect information, there is a first best solution to the problem, namely: that the principal installs the most efficient agents, taking (1) and (2) into account. However, given asymmetric information the principal is forced to look for second best solutions that all will involve a better deal for the agents.

In Rawlsian well-ordered societies, the political agents in government operate the set of governance mechanisms that we call "state" (Kelsen, 1961; 1967). It claims sovereignty over 
its country, but it enters into a web of relationships with other states, governed by the rule of law principles of the international society, namely the so-called public international law (Schwobel, 2011).

A state may be seen as flowing from an agreement among the members about helping each other in securing peace and stability. A body of rules would codify this mutual agreement. A state quickly develops a division of labour between leaders and followers, the subgroup who implements the rules and the subgroup who follow the rules in their behaviour. I will call the followers the "principal" of the political club and the leaders the "agents". Thus, the political club will be modelled as confronted by the principal-agent problematic, comprising inter alia:

- Who are the political agents?

- How are these agents selected?

- Can agent power be laid down formally?

- Are there restraints on the power of the agents?

In politics, transaction costs are minimised by handing over the responsibility for the tasks of the state to a set of people, called the leaders and their public servants. I will employ the word: "agents". The agents provide the members of the state - the citizenry or the principal - with the chief goods and services of this type of community, when they are successful that is.

\section{Literature}

Adamson, P., \& Taylor, R. C. (Eds.). (2004). The Cambridge Companion to Arabic Philosophy. Cambridge: Cambridge University Press. http://dx.doi.org/10.1017/CCOL0521817439\%20

Adib-Moghaddam, A. (2014). A Critical Introduction to Khomeini. Cambridge: Cambridge University Press. Ahktar, S. (2007). The Quran and the Secular Mind: A Philosophy of Islam. London: Routledge.

Al-Tamany, S. M. S. (2014). Averroes, Kant and the Origins of the Enlightenment: Reason and Revelation in Arab Thought. London: I.B. Tauris.

Albert, G. and A. Bienfait (eds) (2007) Aspekte des WeberParadigmas: Festschrift fã $1 / 4$ r Wolfgang Schluchter. Verlag f $\tilde{A} 1 / 4$ r Sozialwissenschaften.

Averroes. (n. d.). The Decisive Discours. Retrieved from http://people.uvawise.edu/philosophy/phil205/Averroes.html\%20

Beaud, M. (2006) A History of Capitalism 1500-2000. Aakar Books.

Bendix, R. $(1960,1992)$ Max Weber â An Intellectual Portrait. Berkeley: University of California Press. Bendix, R. and G. Roth (1971) Scholarship and Partnership: Essays on Max Weber. Berkeley: University of California Press.

Besley, T. (2006) Principled Agents? The Political Economy of Good Government. Oxford: Oxford University Press.

Bruun, H.H. $(1972,2012)$ Science, Values and Politics in Max Weber's Methodology: New Expanded Edition. Aldershot: Ashgate Publishing.

Bruun, H.H. and S. Whimster (eds) Max Weber: Collected Methodological Writings. London: Routledge, 2012.

Calvert, J. (2010). Sayyid Qutb and the Origins of Radical Islamism. New York: Columbia University Press.

Calvert, J. (2010) Sayyid Qutb and the Origins of Radical Islamism. C Hurst.

Chaudhuri, K. (2010) Trade and Civilisation in the Indian Ocean: An Economic History from the Rise of Islam to 1750. Cambridge: Cambridge U.P.

Cheibub, J.A. (2006) Presidentialism, Parliamentarism, and Democracy. Cambridge: Cambridge University Press.

Cheibub, J.A. (2006) Presidentialism, Parliamentarism, and Democracy. Cambridge: Cambridge University Press.

Cooter, R. D., \& Ulen, T. (2011). Law and Economics. New York: Pearson.

Davidson, L. (2013) Islamic Fundamentalism: An Introduction. Praeger. 
Diamond, L. (1999) Developing Democracy.: Towards Consolidation. Baltimore: John Hopkins U.P.

Diamond, L. (1999) Developing Democracy.: Towards Consolidation. Baltimore: John Hopkins U.P.

Easton, D. (1965). A Systems Analysis of Political Life. New York: Wiley.

Elgie, R. and Sophia Moestrup (2008) (eds) Semi-presidentialism in Central and Eastern Europe. Manchester: Manchester University Press.

Elgie, R. and Sophia Moestrup (2008) (eds) Semi-presidentialism in Central and Eastern Europe. Manchester: Manchester University Press. Friedman, M. (2002) Capitalism and Freedom. Chicago: University of Chicago Press. Friedman, M. (2008) Milton Friedman on Economics: Selected Papers. Chicago: Chicago University Press .

Ellis, M., Emon, A. M., \& Glahm, B. (Eds.). (2010). Islamic Law and International Human Rights Law. Oxford: Oxford University Press.

Fakhry, M. (2004). A History of Islamic Philosophy. New York: Columbia University Press.

Friedman, M. (2002) Capitalism and Freedom. Chicago: University of Chicago Press.

Friedman, M. (2008) Milton Friedman on Economics: Selected Papers. Chicago: Chicago University Press-

Glahn von, R. (2016) The Economic History of China. Cambridge: Cambridge U.P.

Glasenapp von, H. (1951-52) Die fÃ¹/4nf grossen Religionen: Two volumes. Dusseldorf/KÃ Tln: Diederichs.

Gordon, S. (2002) Controlling the State: Constitutionalism from Ancient Athens to Today, Harvard U.P.

Gordon, S. (2002) Controlling the State: Constitutionalism from Ancient Athens to Today, Harvard U.P.

Hallaq. (2010). An Introduction to Islamic Law. Cambridge: Cambridge University Press.

Hardin, R. (2003) Liberalism, Constitutionalism, and Democracy, OUP

Hardin, R. (2003) Liberalism, Constitutionalism, and Democracy, OUP

Held, D. (1995). Democracy and the Global Order: From the Modern State to Cosmopolitan Governance. Stanford: Stanford U.P.

Hobbes, T. (1982). Leviathan. London: Pemguin. Jackson, R. (2010).

Huff, T. E. and W. Schluchter (1999) Max Weber and Islam. Piscataway: Transaction Publishers. .

IMF (2009) World Economic Outlook Database; data available from:

http://www.imf.org/external/pubs/ft/weo/2009/01/weodata/index.aspx\%20

IMF (2009) World Economic Outlook Database; data available from: http://www.imf.org/external/pubs/ft/weo/2009/01/weodata/index.aspx\%20

Jackson, R. (2010) Mawlana Mawdudi and Political Islam. London: Routledge.

Kamali, M. H. (2008). Shari'ah Law: An Introduction. Oneworld Publications.

Kaufmann, D., Kraay, A., \& Mastruzzi, M. (2010). The Worldwide Governance Indicators: Methodlogy and analytical issues. World Bank Policy Working paper No 5430.

http://papers.ssrn.com/sol3/papers.cfm?abstract_id=1682130

Kavalski, E. and Magdalena Zolkos (2008) (eds) Defunct Federalisms: Critical Perspectives on Federal Failure. Aldershot: Ashgate.

Kavalski, E. and Magdalena Zolkos (2008) (eds) Defunct Federalisms: Critical Perspectives on Federal Failure. Aldershot: Ashgate.

Keefer, P. (2007) DPI2006 Database of Political Institutions: Changes and Variable Definitions, Washingotn, DC: The World Bank; available from: http://go.worldbank.org/2EAGGLRZ40.\%20

Keefer, P. (2007) DPI2006 Database of Political Institutions: Changes and Variable Definitions, Washingotn, DC: The World Bank; available from: http://go.worldbank.org/2EAGGLRZ40.\%20

Kelsen, H. (2009) Pure Theory of Law. London: The Lawbook Exchange.

Kelsen, H. (2009) Pure Theory of Law. London: The Lawbook Exchange.

Klabbers, J., Peters, A., \& Ulfstein, G. (2011). The Constitutionalization of International Law. Oxford: Oxford U.P.

Kocka, J. (2016) Capitalism: A Short History. Princeton: Princeton U.P. 
Krisch, N. (2011). Beyond Constitutionalism: The Pluralist Structure of Postnational Law.

Kumar, D. and M. Desai (1983) (eds) The Cambridge Economic History of India: Volume 2, c.1751-c.1970.

Cambridge: Cambridge U.P.

Lane, J.-E. (2011). Constitutions and Political Theory. Manchester: Manchester U.P.

Lane, J.-E. and Ersson, S. (2000) The new institutional politics: Performance and outcomes. London: Routledge.

Lane, J.-E. and Ersson, S. (2000) The new institutional politics: Performance and outcomes. London: Routledge.

Leaman, O. (2009). Islamic Philosophy: An Introduction. Cambridge: Polity Press.

Leaman, O. (2009). Islamic Philosophy: An Introduction. Cambridge: Polity Press.

Lundell, K. and L. Karvonen (2008) A Comparative Data Set on Political Institutions â $\diamond$ An Update, Ã bo:

$\tilde{A} \curvearrowright$ bo Academy.

Lundell, K. and L. Karvonen (2008) A Comparative Data Set on Political Institutions â An Update, Ã bo:

Â bo Academy.

Mainwaring, S. and Matthew Soberg Shugart (1997) (eds), Presidentialism and Democracy in Latin America. Cambridge: Cambridge University Press.

Mainwaring, S. and Matthew Soberg Shugart (1997) (eds), Presidentialism and Democracy in Latin America. Cambridge: Cambridge University Press.

Malthaner, S. (2011). Mobilizing the Faithful: Militant Islamist Groups and Their Constituencies. Chicago: University of Chicago Press.

Manne, R. (2016) The Mind of the Islamic State: Milestones Along the Road to Hell. Black Inc. Redback.

Mawlana Mawdudi and Political Islam: Authority and the Islamic state. London: Routledge.

Miller, T and Kim R. Holmes (2009) Index of Economic Freedom. The Heritage Foundation.

Miller, T and Kim R. Holmes (2009) Index of Economic Freedom. The Heritage Foundation.

Mommsen, W. J. 2004) Max Weber und die deutsche Politik 1890-1920. Tuebingen: Mohr und Siebeck.

Nasr, S. H. (2006). Islamic Philosophy from Its Origin to the Present: Philosophy in the Land of Prophecy. New York: State University of New York.

Neal, L. and J.G. Williamson (2015) (eds) The Cambridge History of Capitalism, 2 Volumes. Cambridge: Cambridge U.P.

Rapoport, Y., \& Ahmed, S. (Eds.). (2010). Ibn Taymiyya and his Times. Oxford: Oxford University Press. .

Raz, J. (2009) The Authority of Law. Oxford: Oxford U.P.

Reiss, H.S. (ed.) (2005) Kant: Political Writings. Cambridge: Cambridge U.P.

Reiss, H.S. (ed.) (2005) Kant: Political Writings. Cambridge: Cambridge U.P.

Riker. W. (1975) â? Federalismâ?, in Handbook of Political Science, eds. Greenstein, F. and Nelson Polsby, Vol 5. New York: Addison-Wesley, pp 93-172.

Riker. W. (1975) â $\widehat{\gamma}$ Federalismâ Vol 5. New York: Addison-Wesley, pp 93-172.

Ringer, F. (2004) Max Weber: An Intellectual Biography. Chicago: University of Chicago Press

Rodinson, M. (1993) L'islam: Politique et croyance. Paris: Fayard.

Rodinson, M. (1994) Mahomet. Paris: Seuil

Rodinson, M. (2009) Islam and Capitalism. Paris: Saqi.

Roy, O. (2009). The Politics of Chaos in the Middle East. Oxford: Oxford U.P.

S., Baranger, D. and Anthony W. Bradley (2007) Constitutionalism and the role of -parliaments, Oxford : Hart, 2007 .

Samuelson, K. (1964) Religion and Economic Action. A critique of Max Weber. New York: Harper Torchbooks. 
Sayed, K. (2009). The Political Thought of Sayyid Qutb: The Theory of Jahiliyyah. London: Routledge.

Sombart, W. (2001) Economic Life in the Modern Age. Piscataway: Transaction Publishers.

Tawney, R. H. (1922, 2012) The Acquisitive Society: Greed and Society. London: CreateSpace Independent Publishing

Tawney, R. H. (1930, 2015) Religion and the Rise of Capitalism. Verso.

The Koran. (1995). London: Penguin.

Tsebelis, G. (2002) Veto Players: How Political Institutions Work. Princeton: Princeton University Press.

Tsebelis, G. (2002) Veto Players: How Political Institutions Work. Princeton: Princeton University Press.

UNDP (2008) Human Development Indices: A statistical update 2008; data available from:

http://hdr.undp.org/en/statistics/data/hdi2008/\%20

UNDP (2008) Human Development Indices: A statistical update 2008; data available from: http://hdr.undp.org/en/statistics/data/hdi2008/\%20

Weber, M. (1947) The Theory of Social and Economic Organisation. With an introduction by T. Parsosns. New York: Free Press.

Weber, M. (1949) The Methodology of the Social Science. New York: Free Press.

Weber, M. (1978) Economy and Society I-II. Berkeley: University of California Press.

Weber, M. (2001) Economie et societe dans l'Antiquite. Paris: La Decouverte.

Weber, M. (2003) General Economic History. Dover.

Weber, M. 1988. Gesammelte Aufsaetze zur Religionssoziologie I-III. Tuebingen: Mohr. Studentausgabe.

Weber, M. 2010. The Protestant Ethic and the Spirit of Capitalism. Oxford: Oxford U.P.

Weingast, B.R. (1977) "The Political Foundations of Democracy and the Rule of Law", American Political Science Review, Vol. 91, No. 2, pp. 245-263.

Weingast, B.R. (1977) The Political Foundations of Democracy and the Rule of Law, American Political Science Review, Vol. 91, No. 2, pp. 245-263.

Wittfoget, K. (1957) Oriental Despotism. New Haven: Yale U.P.

World Bank (2009) Governance Matters 2009: Worldwide Governance Indicators, 1996-2008; data available from: http://info.worldbank.org/governance/wgi/index.asp\%20

World Bank (2009) Governance Matters 2009: Worldwide Governance Indicators, 1996-2008; data available from: http://info.worldbank.org/governance/wgi/index.asp\%2022\%20Ziegler, K.

World Bank: Worldwide Governance Indicators (2016): http://data.worldbank.org/data-catalog/worldwidegovernanceindicators. $\% 20 . \% 20$

Ziegler, K. S., Baranger, D. and Anthony W. Bradley (2007) Constitutionalism and the role of parliaments, Oxford : Hart, 2007 . 